NBER WORKING PAPER SERIES

\title{
TRANSPARENCY, RISK MANAGEMENT \\ AND INTERNATIONAL FINANCIAL FRAGILITY
}

\author{
Mario Draghi \\ Frnacesco Giavazzi \\ Robert C. Merton \\ Working Paper 9806 \\ http://www.nber.org/papers/w9806
NATIONAL BUREAU OF ECONOMIC RESEARCH 1050 Massachusetts Avenue
Cambridge, MA 02138
June 2003

An earlier version was presented under the same title as the Geneva Report at the Fourth Geneva Conference on the World Economy: Financial Markets: Shock Absorbers or Shock Creators?, International Center for Monetary and Banking Studies, Geneva, Switzerland, May 10, 2002. Aid from the Centre for Economic Policy Research and the Swiss National Science Foundation is gratefully acknowledged. We thank Alberto Giovannini, Charles Goodhart, Michael Mussa and Elu von Thadden for their comments on an earlier draft, and Agostino Consolo for helpful assistance. Francesco Giavazzi thanks the Houblon-Norman Fund at the Bank of England for its hospitality while part of this work was conducted. The views expressed herein are those of the authors and not necessarily those of the National Bureau of Economic Research.

(C)2003 by Mario Draghi, Francesco Giavazzi, and Robert C. Merton. All rights reserved. Short sections of text not to exceed two paragraphs, may be quoted without explicit permission provided that full credit including (C) notice, is given to the source. 
Transparency, Risk Management and International Financial Fragility

Mario Draghi, Francesco Giavazzi, and Robert C. Merton

NBER Working Paper No. 9806

June 2003

JEL No. F3, G1, G2

\begin{abstract}
Discussions of financial risk often fail to distinguish between risks that are consciously borne and those that are not. To understand the breeding conditions for financial crises the prime focus of concern should not be simply on large risk-taking per se, but on the unintended, or unanticipated accumulation of large risks by individuals, institutions or governments, often through the lack of knowledge or understanding of the risks by stakeholders and overseers of those entities. This paper analyses specific situations in which significant unanticipated and unintended financial risks are accumulated. It focuses, in particular, on the implicit guarantees that governments extend to banks and other financial institutions, which may result in the accumulation, often unconscious from the viewpoint of the government, of unanticipated risks in the balance sheet of the public sector. The paper also discusses how risk exposures can be measured, hedged and transferred through the use of derivatives, swap contracts, and other contractual agreements with specific reference to emerging markets.
\end{abstract}

$\begin{array}{lll}\text { Mario Draghi } & \text { Francesco Giavazzi } & \text { Robert C. Merton } \\ \text { Vice Chairman } & \text { Professor of Economics } & \text { John and Natty McArthur } \\ \text { Goldman Sachs } & \text { International Bocconi University } & \text { University Professor } \\ \text { 132 Fleet Street } & \text { 20136, Milano } & \text { Harvard Business School } \\ \text { London EC4 } & \text { Italy } & \text { Boston, MA 02163 } \\ \text { mario.draghi@cs.com } & \text { francesco.giavazzi@uni-bocconi.it } & \text { and NBER }\end{array}$




\section{Risk and transparency}

Well-functioning financial markets carry out many tasks: the transfer of value over time (borrowing-lending), across borders and industries, the facilitation of payments, the fragmentation of large-size investment projects. An important latent function of financial markets is to provide timely information: on the expectations of economic agents and on the value of the economy's assets.

But perhaps the foremost function financial markets perform is the transfer or allocation of risk among different actors: young people, for instance, tend to be better equipped in taking on risk than old people. Given a total amount of risk in the economy, financial markets and financial institutions contribute to its distribution among different actors in a way that better fits individual preferences or conditions.

Financial markets, however, are often "incomplete", in the sense that they provide only limited possibilities to shift risk across individuals. The role of swaps and other privately negotiated derivative instruments is to complete financial markets, thus increasing the ability of individuals, financial institutions, corporations and governments to manage risk.

\subsection{Risk and derivatives}

Consider, for example, an emerging market economy. The domestic financial market will typically allow very limited diversification of risks. In such a situation, diversification through international capital mobility is the obvious alternative. However, the transfer across borders of the ownership of real and financial assets is a rather inflexible way to achieve diversification, in the sense that it is costly to reverse. Often it also runs against political constraints.

Over-the-Counter (OTC) derivative contracts provide an appealing alternative. Equity swaps, for instance, allow a country to diversify risk without shifting the ownership of assets. For example, a government could impose tight capital controls, limit foreign ownership of 
domestic firms and still diversify the country's exposure to domestic risk through equity swap contracts with foreigners that do not require the transfer of ownership of the underlying asset.

The general point is that risk diversification through derivative instruments is more flexible than diversification through the transfer of assets. Interest rate swaps, for instance, one of the most common of these instruments, allow banks to service both their borrowers, who want fixed-interest rate, long-dated loans and their depositor lenders, who do not wish to be exposed to interest rate risk, without the bank taking interest rate exposure itself. Creditdefault swaps allow a bank to swap credit risk vis-à-vis one borrower for credit risk vis-à-vis a different set of borrowers: the risk-return performance of the bank may thus be improved without negatively affecting its relationship with customers - as might happen if the bank were to sell the loans. We discuss these instruments further in Section 6 of this paper.

A volatile economic environment increases the incentive to use derivatives to achieve a better allocation of risk in the economy. During the first half of 2002, as uncertainty in the world economy was increasing, the size of the OTC derivatives market (foreign exchange, interest rate, equity-linked and commodity contracts), increased by 15 percent, reaching $\$ 127,564$ billion. Outstanding credit derivatives, a type of instruments, which did not exist up to the mid-nineties, increased 35 percent, reaching $\$ 1,600$ billion. ${ }^{1}$

As derivatives markets expand, however, so do the concerns regarding the possibility that the use of these instruments might increase the vulnerability of the financial system, rather than contribute to a better allocation of risks. These concerns were well summarized in a recent IMF paper: "OTC derivative contracts bind institutions together in an opaque network of credit exposure, the size and characteristics of which can change rapidly and, moreover, are arguably not fully understood with a high degree of accuracy even by market participants themselves. Risk assessments and management of exposures are seriously complicated by a lack of solid information and risk analyses about the riskiness of both their own positions and those of their

\footnotetext{
${ }^{1}$ Data from the B.I.S. and the International Swaps and Derivatives Association.
} 
counter-parties. As a result this market is characterized by informational imperfections about current and potential future credit exposures and market-wide financial conditions." ${ }^{2}$ The collapse of Enron and the view that the company's use of derivatives was a factor in its demise - a view by no means uncontroversial, as discussed in ISDA, 2002--only added to these concerns.

Discussions of the role of derivatives and their risks, as well as discussions of financial risks in general, often fail to distinguish between different types of risk. To understand the breeding conditions for financial crises the prime source of concern is not risk per se, but the unintended, or unanticipated accumulation of risks by individuals, institutions or governments including the concealing of risks from stakeholders and overseers of those entities.

To make this point, the paper analyses specific situations in which significant unanticipated and unintended financial risks are accumulated. Among the examples concerning the public sector are the explicit and implicit guarantees that governments extend to banks and other financial institutions. Such guarantees can be the source of unrecognised accumulation by governments of unanticipated risks and resulting liabilities in the balance sheet of the public sector. ${ }^{3}$

We shall analyze how the value of such guarantees changes with the change in the value of the economy's assets, and what this implies for a government's financial policy, and thus for the sustainability of the public debt. This analysis will naturally lead to a set of reflections on the correct evaluation of a country's exposure to risk and on the design of prudential rules for banks and for their shareholders. It will also lead to a discussion of the way financial instruments, such as swaps, could be used to control the accumulation of risk.

\footnotetext{
${ }^{2}$ Schinasi, Garry, J. et al. (2000, p. 50). The paper provides a thorough review of the problems associated with the use of derivative instruments.

${ }^{3}$ These unexpected outcomes of economic actions are specific instances of the more general concept of unanticipated consequences of social actions. See R. K. Merton (1936, 1989).
} 


\subsection{Transparency and accounting principles}

There are situations where the unintended, or unanticipated accumulation of risks may be a sheer consequence of inadequate accounting principles that conceal risk itself. An important example of the limitations of standard accounting principles in identifying and revealing large risk exposures is offered by the treatment of company pension funds - a topic we take up in the next section of the paper.

The demise of Enron has attracted much attention on the lack of transparency of leverage and risk-taking by firms that move liabilities and risk exposures off their balance sheets by using complex special-purpose partnerships and derivatives. The same financial engineering tools that have served well in the efficient transfer of risks across otherwise incompatible

institutional systems, may also be used to disguise large risks and value losses from even the most diligent of detectors.

The danger of abuse, and thus a need that corporate managers, board members and other external overseers understand these instruments, has been rightly emphasized following the Enron events. Indeed, the boards of many firms are engaging outside risk specialists to search for what they call "Enronitis" among their subsidiaries and capital structures. However, this bright-light focus on modern financial technology can blind us to more fundamental issues surrounding the limitations of traditional accounting. One need look no further than to the familiar, plain-vanilla, "well-understood" defined-benefit corporate pension plan as an example of these limitations. Such plans present a far larger in magnitude and more widespread off-balance sheet leverage, than any of the Enron transactions, and without reliance on complex derivative contracts at all. 


\section{Risk and (lack of) transparency in U. S. balance sheets: the economic effects of the accounting treatment of defined-benefit pension plans}

A defined-benefit $(D B)$ pension plan represents a secured claim by the plan's beneficiaries against the company - typically a guarantee of a pension of up to two-thirds of final salary. The plan's assets constitute collateral-like security for promised benefits. From an economic standpoint, this is equivalent to the company borrowing money to invest in assets. For this reason a company that does not wish to use the defined-benefit pension plan it sponsors to increase its asset risk and its leverage should invest 100 percent of the plan's assets in highly rated, fixed-income, securities, the duration of which matches the duration of the plan's liabilities. This however is not what most companies do. ${ }^{4}$

\subsection{GAAP rules and companies' exposure to risk via the pension plans they sponsor}

Generally accepted accounting principles in the United States (GAAP, Statement of Financial Accounting Standards No. 87, SFAS 87) direct public companies that sponsor a defined-benefit (DB) pension plan to report, in their balance sheet and income statement, only the net difference between the company's pension assets and liabilities, as a corporate asset or liability. Thus what enters the company's balance sheet is only the surplus (deficit), which is the difference between the value of the plan's assets and its liabilities. For example, a plan with $\$ 65$ billion in assets and $\$ 64$ billion in pension liabilities would report a net amount of surplus of $\$ 1$ billion, the same as a plan with $\$ 2.5$ billion in assets and $\$ 1.5$ billion in liabilities. The amount of risk a company accumulates in its balance sheet, via the exposure to its pension plan, thus is not immediately visible.

Table 1 shows the balance sheet of a hypothetical company that sponsors a DB pension plan. The case shown in the table is that of a company whose plan is fully funded - that is, at current market prices assets and liabilities are matched. This of course would not be the case if, for instance, interest rates subsequently changed. 
Table 1

Balance sheet of a company sponsoring a defined-benefit pension plan

(The case shown is that of a company whose plan is fully funded)

Assets

Liabilities

\begin{tabular}{c|cc} 
Capital & $\mid$ & - Equity \\
& $\mid$ & \\
off-balance sheet: & $\mid$ & \\
Pension Fund Assets: & DB Plan Liabilities \\
- Bonds 40 & | 100 \\
- Stocks 60 & $\mid$
\end{tabular}

For example, if the pension plan's assets are partly (for the typical U.S. plan around 60\%) invested in stocks, then a simultaneous fall in both interest rates and stock prices - as might happen during a recession or in a financial crisis with a flight to quality-would increase the value of the plan's liabilities — which rise as interest rates fall — and at the same time reduce the value of the assets held as collateral for those liabilities. The company's economic balance sheet is thus exposed to the volatility of the plan's assets and liabilities. ${ }^{5}$

The accounting treatment of a DB pension plan is thus little different from the treatment of an off-balance-sheet long-dated swap derivative contract in which the company receives the total return on an equity portfolio and pays a fixed rate of interest in return applied to a notional amount equal to pension liabilities.

\footnotetext{
${ }^{4}$ For an extended discussion see Bodie, Mitsui and Tufano (2002).

${ }^{5}$ We believe that the correct way to compute the value of a plan's liabilities is to use the yield on a longterm default-free bond as the discount rate since in this case liabilities are valued using a discount rate that has the same risk and timing characteristics as the payments the plan will make. This belief, however, is not undisputed. When stock markets fall, some actuaries hold that the fall in asset prices does not matter for the solvency of a pension plan, because, as share prices decline, the dividend yield rises and the expected return on the market increases. Accordingly, as the assets decline, so does the actuarially measured values of the liabilities - assuming this is computed using the dividend yield, as discount rate.
} 
Therefore, a standard U.S. corporate pension plan may produce the same leverage and potentially large risk, as would the use of an equivalent derivative contract, with neither directly reported on the balance sheet.

\subsection{Pension plans, income statements and bonuses}

GAAP rules allowing a company to account for the surplus income from its DB pension plan as operating income, can obscure any assessment of the company's performance. Consider, for example, a good-performing year, that is a year in which the return on the pension plan's assets is particularly good and exceeds what would be required to match the increase in the plan's liabilities. GAAP rules allow this excess return to be credited as a new intangible asset, called "prepaid benefit expense". The opposite adjustment can be made in a bad year.

The beneficiaries of excess return are not the plan's beneficiaries, but the company's shareholders who can draw on this intangible asset to top up the company's net income. For example, in 2001 Verizon Communications Inc. reported a net income of \$389 million, after taking losses for a variety of telecom investments. The "true" net income, however was a loss of $\$ 1.8$ billion: The net income was turned positive by drawing on the excess return on the assets of the company's pension plan.

Milliman USA, a benefits consulting firm, reports that in 2001 the net income declared by 50 large U.S. corporations included $\$ 54.4$ billion of excess returns from pension funds' assets. In fact, these assets lost $\$ 35.8$ billion. $^{6}$

Discretion on the part of companies in their treatment of the returns on pension fund assets, and thus lack of transparency, extends far beyond. Keeping to the Verizon example, if one looks more closely at the company pension plan, one finds that in 2001 the return on the plan's assets was negative, and resulted in a reduction in the value of total assets amounting to

\footnotetext{
${ }^{6}$ www.milliman.com
} 
$\$ 3.1$ billion. How then could the company claim an excess return and report it on its income statement?

GAAP rules are based on the assumption that over time positive and negative returns on a pension plan's assets will balance out. A company's accounting is thus expected to understate both its plan's losses in bad years and its plan's gains in good years. In economic terms shareholders should benefit from the pension plan's income with smaller contributions in good years, and pay more into the plan in bad years. This is not what always happens in accounting terms. Verizon's 2001 income statement "assumes" that its pension plan had earned a return of 9.25 percent and it reported income as if that assumption were true. Other companies made even more bold assumptions: IBM assumed a return of 10 percent, General Electric of 9.5 percent. In Verizon's case, the income associated with a return of 9.25 percent would have exceeded the amount required to balance the increase in the liabilities of the company's pension plan: thus the origin of the "excess" return.

The incentives to legally manipulate the return on a company pension plan are enhanced by the practice of including the income assumed to have been originated from the pension plan's assets when computing management's performance bonuses.

However, when a plan slips into underfunded status - as might happen when the fall in asset prices and interest rates do not reverse and eventually must be recognized in the company's accounts - a corporation's equity may take a hit that can disproportionately exceed the year's charge to the DB pension plan. This is because SFAS 87 requires a corporation whose plan falls into unfunded status to take two actions:

charge to the balance sheet a minimum liability equal to the amount underfunded. Thus, for a pension plan for which the minimum liability is required, all losses of the plan for the year-including the full effect of higher liability measured at the new lower interest rates and asset losses in the weak markets - are immediately reflected as reductions in shareholder equity; 
cancel any asset that had been created in the corporation's balance sheet as a result of the accumulation of excess returns on the pension plan's assets during the previous years. The charge for such cancellation is taken by shareholders' equity.

To illustrate, assume a plan was previously overfunded, generating a positive contribution (negative annual cost of the plan) to the income statement in prior years. These positive contributions appear as a prepaid pension cost, an asset item on the company's balance sheet. Now assume that the plan is no longer overfunded due to investment losses and/or an increase in obligations. The consequence of the minimum liability calculation is that:

. the prepaid pension cost (an asset) must be eliminated, and

- an accrued pension cost (a liability) equal to the amount of underfunding must be carried on the balance sheet.

The combined effect of these changes can be a significant adjustment to shareholder equity as illustrated in Table 2. Note that in this example, the company's equity is reduced not merely by the $\$ 1,000,000,000$ underfunding, but by the reversal of the entire previously accumulated prepaid pension cost as well.

Table 2

Balance sheet effects of the minimum liability requirement in the case of unfunded DB plans (U.S. \$ billion)

\begin{tabular}{|c|c|c|c|}
\hline & $\begin{array}{l}\text { Initial } \\
\text { Measurements }\end{array}$ & $\begin{array}{l}\text { Adjustment for } \\
\text { Minimum Liability }\end{array}$ & $\begin{array}{l}\text { Final } \\
\text { Figures }\end{array}$ \\
\hline Accumulated benefit obligation & 50 & & 50 \\
\hline Assets & 49 & & 49 \\
\hline Unfunded & 1 & & 1 \\
\hline Accrued/(Prepaid) pension expe & ise & 6 & 1 \\
\hline
\end{tabular}

Note: The U.S. $\$ 6$ billion adjustment is treated as a direct reduction in shareholder equity. 


\subsection{The transfer of risks onto the government}

GAAP accounting principles thus conceal on a year-on-year basis a company's true exposure to market volatility, which should include the substantial exposure acquired through the assets and liabilities of its pension plan.

Full disclosure, on corporate balance sheets, of the composition of a pension plan's assets (or, in the absence of it, continuous matching of the mark-to-market value of the plan's assets with that of its liabilities) would reveal the true degree of the company's leverage and risk. This is not something that is being considered in current proposals for an overhaul of GAAP rules. $^{7}$

How widespread is the problem? For many of the largest 50 U.S. companies (see Table 3) DB plans account for the bulk of the company's pension plan assets. The remaining pension assets are accounted for by defined-contribution plans, such as 401(k). These assets collectively can be a multiple of the company's market capitalization. In December 2001 the pension assets of General Motors, the largest corporate pension plan in the United States with over $\$ 73$ billion in defined-benefit plan assets, were 2.7 times the company's stock market value. As inspection of Table 2 reveals, GM is certainly not alone in this position among U.S. corporations. Corporate pension assets in total represent a significant fraction of the overall market value of U.S. corporate equity, over one-fourth. Sixty percent, on average, of the assets of defined-benefit plans are invested in common stocks: the fraction has increased from about 50 percent in the 1980 's. ${ }^{8}$

As long as the company is solvent, the risks and rewards of allocating the plan's assets to equities are borne by shareholders, since the fund's beneficiaries enjoy a defined benefit with no upside. However, if the company were to go into bankruptcy, the risks are transferred in part to the beneficiaries, and in part to the federal government through the Pension Benefit

\footnotetext{
${ }^{7}$ For a proposal in this direction see Peter Hancock and Roberto Mendoza "Risk and Transparency in Pensions", Financial Times, March 20, 2002, page 21.

${ }^{8} \mathrm{GM}$ announced In January 2003 that its pension fund assets were unfunded by $\$ 19.3 \mathrm{bn}$, compared with $\$ 9.1$ bn a year earlier (Financial Times, January 10, 2003, page 21.)
} 
Guarantee Corporation (PBGC), the government institution offering partial guarantee to the beneficiaries of the companies' DB plans. Therefore, when a company invests the assets of its pension plan in common stock it is de-facto raising its leverage, and transferring, at least in part, the risk onto the plan's beneficiaries and onto the government.

Negative shocks to the corporate sector can thus be transferred, through company pension funds to the government. An example is shown in Table 4. We assume that the pension plan (a DB plan with government guarantee) is invested $50 \%$ in equity. A negative shock to the corporate sector reduces the value of its assets by 40 percent, causing a 30 percent fall in equity. The fraction of the pension plan's assets invested in equity also falls by 30 percent. In a DB plan the liabilities are unaffected by the shock. Therefore the government's financial exposure to the plan increases by a corresponding amount.

The effects of the transfer of risk onto the government are apparent in the balance sheet of the PBGC for the year ended on September 30, 2002. ${ }^{9}$ During this period the operating loss of the corporation amounted to $\$ 3.64$ billion, an $\$ 11.37$ billion net turnaround from a $\$ 7.73$ billion surplus a year earlier, the largest in the federal pension insurer's 28 -year history. Of these losses, by far the largest fraction, $\$ 9.31$ billion, is accounted for by the increase in "Claims for actual and probable pension plan terminations", that is for the pension obligations transferred to the PBGC by company plans in default, plus the increase in the value of the guarantees extended. This loss arises because, under GAAP, the PBGC recognizes as a loss both actual and probable pension plan terminations. During fiscal year 2002, \$5.91 billion of the $\$ 9.31$ billion in losses were from "probables." Since the close of the 2002 fiscal year, the agency has assumed full responsibility for the pension plans of two companies-National Steel and Bethlehem Steel-that together accounted for $\$ 5.16$ billion of the losses estimated as "probable" on September 30. Another key factor was the decline in interest rates, which increased the program's liabilities by $\$ 1.65$ billion.

\footnotetext{
${ }^{9}$ The balance sheet is available at www.pbgc.gov.
} 
Table 3: Largest 50 U.S. Corporate Defined Benefit Pension Funds as of December 31, 2001

\begin{tabular}{|c|c|c|c|c|c|}
\hline & Company Name & $\begin{array}{c}\text { U.S. Defined Benefit } \\
\text { Pension Assets, } \\
12 / 31 / 01, \\
\text { \$ million }^{\mathrm{a}} \\
\end{array}$ & $\begin{array}{l}\text { U.S. Defined Benefit } \\
\text { Pension Liabilities, } \\
\text { (PBO as of 12/31/01), } \\
\$ \text { \$ million }{ }^{\mathrm{a}} \\
\end{array}$ & $\begin{array}{c}\text { Total Assets of } \\
\text { Sponsor, 12/31/01 } \\
\text { \$ million } \\
\end{array}$ & $\begin{array}{c}\text { Market Value of } \\
\text { Sponsor, 12/31/01 } \\
\text { \$ million }\end{array}$ \\
\hline 1 & GENERAL MOTORS CORP & 73,662 & 86,333 & 323,969 & 26,997 \\
\hline 2 & INTL BUSINESS MACHINES CORP & 61,096 & 60,410 & 88,313 & 208,371 \\
\hline 3 & FORD MOTOR CO & 48,754 & 51,214 & 276,543 & 27,368 \\
\hline 4 & VERIZON COMMUNICATIONS & 48,558 & 36,391 & 170,795 & 128,828 \\
\hline 5 & GENERAL ELECTRIC CO & 45,006 & 30,423 & 495,023 & 398,105 \\
\hline 6 & LUCENT TECHNOLOGIES INC ${ }^{\mathrm{b}}$ & 35,539 & 29,850 & 33,664 & 21,510 \\
\hline 7 & BOEING CO & 33,810 & 32,693 & 48,343 & 30,945 \\
\hline 8 & SBC COMMUNICATIONS INC & 32,715 & 25,060 & 96,322 & 131,672 \\
\hline 9 & DAIMLERCHRYSLER AG & 28,152 & 30,817 & 184,616 & 42,295 \\
\hline 10 & BP PLC & 22,505 & 20,402 & 141,158 & 177,026 \\
\hline 11 & ROYAL DUTCH PETROLEUM & 21,852 & 19,343 & 66,926 & 105,075 \\
\hline 12 & LOCKHEED MARTIN CORP & 20,300 & 19,713 & 27,654 & 20,559 \\
\hline 13 & AT\&T CORP & 18,485 & 14,035 & 165,282 & 64,180 \\
\hline 14 & DU PONT (E I) DE NEMOURS & 17,923 & 18,769 & 40,319 & 44,197 \\
\hline 15 & BELLSOUTH CORP & 16,617 & 11,928 & 52,046 & 71,606 \\
\hline 16 & NORTHROP GRUMMAN CORP & 13,889 & 12,404 & 20,886 & 11,211 \\
\hline 17 & EXXON MOBIL CORP & 12,170 & 19,419 & 143,174 & 268,833 \\
\hline 17 & PHILIP MORRIS COS INC & 11,720 & 12,222 & 84,968 & 99,343 \\
\hline 19 & DOW CHEMICAL & 11,424 & 11,341 & 35,515 & 30,466 \\
\hline 20 & QWEST COMMUNICATION INTL INC & 11,121 & 9,625 & 73,781 & 23,526 \\
\hline 21 & HONEYWELL INTERNATIONAL INC & 11,051 & 10,952 & 24,226 & 27,502 \\
\hline 22 & CITIGROUP INC & 10,323 & 10,388 & $1,051,450$ & 259,710 \\
\hline 23 & RAYTHEON CO & 10,164 & 11,171 & 26,636 & 12,693 \\
\hline 24 & UNITED TECHNOLOGIES CORP & 10,025 & 12,354 & 26,969 & 30,282 \\
\hline 25 & UNITED STATES STEEL CORP & 8,583 & 7,358 & 8,337 & 1,608 \\
\hline 26 & CATERPILLAR INC & 8,481 & 8,611 & 30,657 & 17,935 \\
\hline 27 & ALCOA INC & 8,434 & 8,488 & 28,355 & 30,196 \\
\hline 28 & DELTA AIR LINES INC & 8,304 & 10,657 & 23,605 & 3,606 \\
\hline 29 & BANK OF AMERICA CORP & 8,264 & 8,135 & 621,764 & 99,041 \\
\hline 30 & $3 \mathrm{M} \mathrm{CO}$ & 8,008 & 8,998 & 14,606 & 46,348 \\
\hline 31 & EASTMAN KODAK CO & 7,942 & 7,439 & 13,362 & 8,562 \\
\hline 32 & TRW INC & 7,902 & 7,482 & 14,444 & 4,687 \\
\hline 33 & UAL CORP & 7,575 & 10,095 & 25,197 & 736 \\
\hline 34 & PG\&E CORP & 7,175 & 6,087 & 35,862 & 7,451 \\
\hline 35 & XEROX CORP & 7,040 & 7,606 & 27,689 & 7,502 \\
\hline 36 & CONSOLIDATED EDISON INC & 6,634 & 5,904 & 16,996 & 8,566 \\
\hline 37 & INTL PAPER CO & 6,502 & 6,419 & 37,158 & 19,447 \\
\hline 38 & UNITED PARCEL SERVICE INC & 6,496 & 5,347 & 24,636 & 18,302 \\
\hline 39 & GENERAL DYNAMICS CORP & 6,107 & 5,162 & 11,069 & 16,070 \\
\hline 40 & DEERE \& CO & 5,951 & 6,440 & 22,663 & 10,364 \\
\hline 41 & CHEVRONTEXACO CORP & 5,947 & 7,028 & 77,572 & 95,640 \\
\hline 42 & PFIZER INC & 5,648 & 6,956 & 39,153 & 250,526 \\
\hline 43 & FEDEX CORP ${ }^{\mathrm{C}}$ & 5,510 & 6,227 & 13,812 & 15,467 \\
\hline 44 & AMR CORP/DE & 5,482 & 7,422 & 32,841 & 3,445 \\
\hline 45 & UNISYS CORP & 5,215 & 4,816 & 5,769 & 4,002 \\
\hline 46 & SOUTHERN CO ${ }^{\mathrm{b}}$ & 5,109 & 3,760 & 29,824 & 17,341 \\
\hline 47 & BETHLEHEM STEEL CORP. & 4,753 & 6,495 & 4,244 & 59 \\
\hline 48 & AMERICAN ELECTRIC POWER & 4,510 & 4,391 & 47,281 & 14,027 \\
\hline 49 & TEXTRON INC & 4,480 & 3,908 & 16,052 & 5,853 \\
\hline 50 & JOHNSON \& JOHNSON & 4,355 & 5,026 & 38,488 & 181,286 \\
\hline
\end{tabular}

Source: Compustat, Adapted by Akiko M. Mitsui, Research Associate, Harvard Business School on December 1, 2002.

aData in these columns were derived from 10-Ks which use FASB valuation guidelines. Liabilities are based on Projected Benefit Obligations (PBOs) and assets may be fair market or market-related values

bension valuation data as of $9 / 30 / 01$

cPension valuation data as of $5 / 31 / 01$ 
Table 4

$\underline{\text { Risk transfer from the corporate sector to the government through DB company pension funds }}$

\begin{tabular}{lrllll}
\multicolumn{5}{c}{ Corporate balance sheet } \\
Assets & \multicolumn{4}{c}{ Liabilities } \\
\hline Corporate assets & 160 & Debt & 90 & $(-10)$ \\
& $(-40)$ & Equity & 70 & $(-30)$
\end{tabular}

Pension plan
Assets

\begin{tabular}{lr|r} 
Bonds & 10 & Present value of Benefits \\
Corporate equity & 7 & 20 \\
Financial guarantee & $(-3)$ & \\
& 3 & $\mid$ \\
$(+3)$ & $\mid$
\end{tabular}

Government balance sheet

Assets Liabilities

$\begin{array}{lll}\text { A } & \text { I } & \text { A } \\ & \text { I } & \text { Guarantee to the pension plan } \\ 1 & (+3)\end{array}$




\section{Balance sheets and financial guarantees ${ }^{10}$}

The pension-plan example shows how the government can become exposed to shocks that originate in the private sector. Financial guarantees can transfer risk across different sectors in the economy and also produce negative feedback loops that can trigger severe crises. In this section we develop this theme further, showing how the implicit guarantees governments extend to banks and other financial institutions result in the accumulation, often unconscious from the viewpoint of the government, of unanticipated risks in the balance sheet of the public sector.

\subsection{Loans and guarantees}

Any time a bank makes a loan, an implicit guarantee of that loan is involved. To see this, consider the following identity, which holds in both a functional and a valuation sense:

$$
\text { Risky Loan + Loan Guarantee } \equiv \text { Default-free Loan }
$$

this can also be re-written as:

$$
\text { Risky Loan } \equiv \text { Default-free Loan - Loan Guarantee }
$$

Lending by a bank thus consists of two functionally distinct activities: pure default-free lending and the bearing of default risk by the lender ${ }^{11}$. This equivalence of course applies more generally to other forms of debt obligations, not only to bank loans. Whenever a lender makes a loan to anyone other than a default-free government, he is implicitly also selling a guarantee.

\footnotetext{
${ }^{10}$ This section draws heavily on Merton and Bodie (1992)

${ }^{11}$ This identity strictly applies only if (a) the guarantee itself is default-free, and (b) it covers the entire loan. That is, the guarantor will not default on this obligation, and his obligation is to fully make up for any loss on promised payments. Some guarantees have deductibles, or require co-insurance with the debt holder. Tax treatments and other regulatory factors could also affect the identity. While such factors are important in analyzing specific situations, they are not essential in understanding the fundamental functional activity of lending as discussed in the text.
} 
To see this point more clearly, it will perhaps be helpful to think of the lending activity as taking place in two steps:

i. purchasing a guarantee, and

ii. taking up of a loan

Suppose that the guarantor and the lender are two distinct entities. In the first step, the borrower buys a guarantee from the guarantor for, say, $\$ 10$. In the second step, the borrower takes this guarantee to the lender and borrows $\$ 100$ at a default-free interest rate of, say, $10 \%$ per year. The borrower winds up receiving a net amount of $(\$ 100-\$ 10=) \$ 90$ in return for a promise to pay back $\$ 110$ in a year.

Often, of course, the lender and the guarantor are the same entity - for example, a commercial bank - and the borrower simply receives the net $\$ 90$ from the bank in return for a promise to repay $\$ 110$ in a year. The interest rate on the loan is then stated as $22.22 \%$, i.e., $(\$ 110-\$ 90) / \$ 90$. This promised rate reflects both the risk-free interest rate and the charge for the guarantee. To see that the two are separable activities, note that the holder of the risky debt could buy a third-party guarantee for $\$ 10$, as shown in Table 5 . The holder would then be making a total investment of $\$ 90+\$ 10=\$ 100$ and would receive a sure payment of $\$ 110$.

Table 5

The balance sheet of a bank that issues guaranteed debt

(units are in \$)

\begin{tabular}{ll} 
Assets & Liabilities \\
\hline $\begin{array}{c}\text { Risky asset } 90 \\
\text { Guarantee } 10\end{array}$
\end{tabular}


The purchase of any real-world loan is thus functionally equivalent to the purchase of a pure default-free loan and the simultaneous issue of a guarantee on that loan. In effect, the creditor simultaneously pays for the default-free loan and receives a "rebate" for the guarantee of that loan. The magnitude of the value of the guarantee relative to the value of the defaultfree loan component varies considerably. A high-grade bond (rated AAA) is an almost defaultfree loan with a very small guarantee component. A below-investment-grade or "junk" bond, on the other hand, typically has a large guarantee component.

\subsection{Transferring risk onto the government}

The liabilities that banks issue to fund their lending are often guaranteed by the government--typically through deposit-insurance schemes. Here we analyse the effects of these guarantees for the public sector. In particular, and more importantly, we wish to understand how does the risk exposure of the government change as the value of the banks' assets changes?

Table 6 shows the balance sheets for a corporation, for a bank that holds its debt, and for the government. The bank itself is financed in part with debt, in part with equity: the value of the debt, if its promised payments were risk-free, is $\$ 90$. In panel A) there is no guarantee, therefore the debt is risky: its market value is $\$ 85$, lower than its default-free value of 90 . This is because, as in the example discussed above, it reflects the prospect of a lower-than-promised payment in the event of default. In panel A) the government is not involved in guaranteeing the bank: its balance sheet is balanced with assets and liabilities both equal to A.

Next we examine, in panel B), what happens following a shock which reduces the capital of the corporation, and thus also the market value of the bank's asset. The loss is absorbed in part by bondholders and in part by the bank's shareholders - say a third by the former, and two-thirds by shareholders. The market value of the debt falls to $\$ 82=\$ 85-\$ 3$; the bank's equity to $\$ 8=\$ 15-\$ 7$. The government's balance sheet is again unaffected. 
Now let us introduce a government guarantee that makes the bank's debt risk-free. This is shown in panel C). Before the shock, when the capital of the corporation is worth $\$ 200$, and the bank's assets are worth $\$ 100$, the value of the guarantee is $\$ 5$, exactly the amount of the default discount on the non-guaranteed debt. Since the debt is fully guaranteed by the government, the value of shareholders' equity does not change. In the balance sheet of the bank the guarantee is an "off-balance-sheet" item (this is why we write it "below the line"), but its value is fully reflected in the equity of the shareholders. Finally, the guarantee shows up in the government's balance sheet as an additional liability: here too we write it below the line, to reflect that such guarantees are seldom accounted for in the government's books. ${ }^{12}$

The guarantee protects the debt from the effects of the shock to the corporation's balance sheet. This is shown in panel D). Equity falls to $\$ 8$, as in the absence of the guarantee, while the market value of the debt does not move from its risk-free value, $\$ 90$. This of course is possible because the value of the government's guarantee has risen from $\$ 5$ to $\$ 8$, an increase that matches the loss that the debt would have incurred absent the guarantee. The government's balance sheet now reflects the greater value of its guarantee to the banks.

The government's exposure to the guarantee changes, as the value of the underlying variables change. This is because the government guarantee protects the debt from the effects of any shock to the corporation's balance sheet. In the last panel of Table 6, panel E), we examine by how much would the value of the guarantee rise, following a further shock to the capital of the corporation, one that reduces it to $\$ 120$, a further loss of $\$ 40$.

The decline in the value of corporate assets increases the prospect of a default and a lower-than-promised payment to the bank: this reduces the value of the corporation's debt to, say, $\$ 75$. The value of the corporation's equity thus falls to $\$ 45$. Now consider the balance sheet of the bank. Absent the guarantee, the market value of the bank's debt would have fallen,

\footnotetext{
${ }^{12}$ In the United States, the Office of Management and Budget is supposed to estimate the value of all guarantees issued by the government.
} 
say, to $\$ 73$ and the bank's equity to $\$ 2$. The government's guarantee protects the value of its liabilities: it thus amounts to $\$ 17$.

In our examples, the relative proportions in which a fall in the value of the bank's assets is borne by debt and equity--or by equity and the government guarantee-- were simply given exogenously. Understanding the underlying structure and variables that determine the increase in the value of the guarantee, as the capital of the corporation falls, will assist our understanding of how governments, by guaranteeing the bank's debt, can accumulate unanticipated risks--and why even recognizing the liability incurred at a given point in time on a marked-to-market basis is not enough to fully capture the government's changing risk exposure. 
Table 6

Transferring risk onto the government

(units are in \$)

A)

\begin{tabular}{|c|c|c|c|c|c|}
\hline \multicolumn{2}{|c|}{$\underline{\text { Corporation }}$} & \multicolumn{2}{|c|}{ Bank } & \multicolumn{2}{|c|}{ Government } \\
\hline Assets & Liabilities & Assets & Liabilities & Assets & Liabilities \\
\hline \multirow[t]{2}{*}{ Capital 200} & | Loan 100 & Loan 100 & | Debt 85 & & \\
\hline & | Equity 100 & & | Equity 15 & & \\
\hline
\end{tabular}

B)

\begin{tabular}{|c|c|c|c|c|c|}
\hline \multicolumn{2}{|c|}{ Corporation } & \multicolumn{2}{|c|}{ Bank } & \multicolumn{2}{|c|}{ Government } \\
\hline Assets & Liabilities & Assets & Liabilities & Assets & Liabilities \\
\hline Capital 160 & | Loan 90 & Loan 90 & | Debt 82 & & \\
\hline & | Equity 70 & & | Equity 8 & & \\
\hline
\end{tabular}

C)

\begin{tabular}{|c|c|c|c|}
\hline \multicolumn{2}{|c|}{ Corporation } & \multicolumn{2}{|c|}{ Bank } \\
\hline Assets & Liabilities & Assets & Liabilities \\
\hline \multirow[t]{3}{*}{ Capital 200} & | Loan 100 & Loan 100 & | Debt 90 \\
\hline & | Equity 100 & 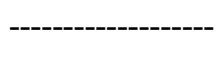 & | Equity 15 \\
\hline & & Gov. Guar. 5 & | \\
\hline
\end{tabular}

D)

\begin{tabular}{|c|c|c|c|c|c|}
\hline \multicolumn{2}{|c|}{ Corporation } & \multicolumn{2}{|c|}{ Bank } & \multicolumn{2}{|c|}{ Government } \\
\hline Assets & Liabilities & Assets & Liabilities & Assets & Liabilities \\
\hline \multirow[t]{3}{*}{ Capital 160} & | Loan 90 & Loan 90 & | Debt 90 & & \\
\hline & | Equity 70 & ----------. & | Equity 8 & & - \\
\hline & & Gov. Gua & | & & 8 Bank Gu \\
\hline
\end{tabular}

E)

\begin{tabular}{ll}
\multicolumn{2}{c}{ Corporation } \\
Assets & Liabilities \\
\hline Capital $\mathbf{1 2 0}$ & | Loan $\mathbf{7 5}$ \\
& | Equity $\mathbf{4 5}$
\end{tabular}

\begin{tabular}{|c|c|}
\hline \multicolumn{2}{|c|}{ Bank } \\
\hline Assets & Liabilities \\
\hline Loan 75 & | Debt 90 \\
\hline & | Equity 2 \\
\hline Gov. Guar. 17 & | \\
\hline
\end{tabular}

Government

\begin{tabular}{ll} 
Assets & Liabilities \\
\hline A $\mid A$ \\
\\
& $\mid$ | 17 Bank Guar.
\end{tabular}




\subsection{Using option theory to measure the exposure to risk}

Guarantees, like options, are contingent liabilities for their issuers, with required future payoffs contingent on the values of other assets. Indeed, the equivalence between a risk-free loan and the combination of a risky loan plus a guarantee suggests the analogy between a loan guarantee and a put option on that loan. The guarantee component of a risky loan is analogous to a put option that is a binding commitment to buy the loan for $\mathrm{V}_{\mathrm{o}}$, the promised value of the loan, in case the borrower, when the loan contract expires, is unable to repay-fully or partially. ${ }^{13}$

In the previous example the position of the holders of the corporation's debt is analogous to a default-free debt combined with a short position in a put option on corporate assets. The economic balance sheet of the bank includes assets consisting of loans to the corporation, which can be decomposed into default-free debt as an asset and the put option as a liability. The bank also holds, among its assets, a government financial guarantee. The government, as the issuer of that guarantee, has it as a liability on its economic balance sheet.

The three economic balance sheets can be used to demonstrate the interdependence among sectors. One is "long" on a certain implicit option; another is "short" on the same implicit option. These implicit options thus create important risk inter-linkages among different sectors.

The analogy between guarantees and options suggests a simple way to measure the exposure to risk arising from a guarantee. For instance, if a government guarantees the liabilities of the banking system, how does its exposure change, as the value of corporate assets changes? Option theory suggests a number of ways to measure exposure to risk. The most common one, "delta", is the change in the value of an option as the value of the underlying asset changes. "Delta" is thus an appropriate measure of an institution's exposure to risk. In our example "delta" could be used to measure to what extent the government's exposure to its 
guarantee changes, as the value of corporate assets, and thus of the assets of the banking system, change. ${ }^{14}$

To construct a measure of exposure to risk using option price theory, we start, in Figure 1, showing two relations. The piecewise linear line is the payoff, at the maturity date, for the holder of a guarantee (the option), as a function of the mark-to-market price of the underlying asset--the bank's loan or the capital of the corporation in the particular case analyzed in the previous section. The payoff is positive for $\mathrm{V}<\mathrm{V}_{\mathrm{o}}$, zero for $\mathrm{V} \geq \mathrm{V}_{\mathrm{o}}$. The other relation plotted in Figure 1 displays the value of the guarantee (the option), as a function of the mark-tomarket price of the underlying asset. This is inversely and non-linearly related to the price of the underlying stock. ${ }^{15}$

Figure 2 shows the government's exposure to risk for any given value of the bank's assets. The curve plotted in this figure is (the absolute value of) the tangent slope of the curve shown in Figure 2--that is of the value of the guarantee, for a date prior to the maturity of the asset. This curve (the "delta") measures by how much the value of the guarantee changes as the value of the banks' assets change. It shows that the government's exposure, acquired through the guarantee, for certain ranges of values increases more than proportionately as the market value of the bank's assets falls.

The reference to the activities of investors is suggestive of how the government's exposure changes as asset prices fluctuate. The additional liability transferred on the government's balance sheet by a 10 percent shock to the capital of firms is larger the lower is

\footnotetext{
${ }^{13}$ If the loan can default before maturity, the guarantee corresponds to an American option, where the exercise date is not predetermined. See Merton $(1974,1977)$.

14 "Delta" is sometimes also called the "hedge ratio". This is with reference to the activities of investors who "hedge" their position in put options by buying shares in the underlying stock. Because the price of the option rises as the value of the underlying asset falls, an investor who owns one put option, and wishes to hedge, must buy a number of shares that is larger the lower is the price of the stock. The "hedge ratio" increases as the value of the underlying asset falls. See e.g. Hull (2000), pp. 310-319.

${ }^{15}$ The figure is created using the option formulas developed in Black-Scholes (1973) and in Merton (1973) with the following parameter values:

- $\quad$ risk free rate $=.04 \quad-\quad$ volatility $=.50$

- time to maturity $=1$ year $\quad$ - strike price $=105$
} 
that capital to start with. Recognizing this point about the non-linearity in the transmission of risk exposures is essential to prevent the accumulation of unanticipated risks on the government's balance sheet.

Figure 1:

VALUE AND PAYOFF OF A GUARANTEE

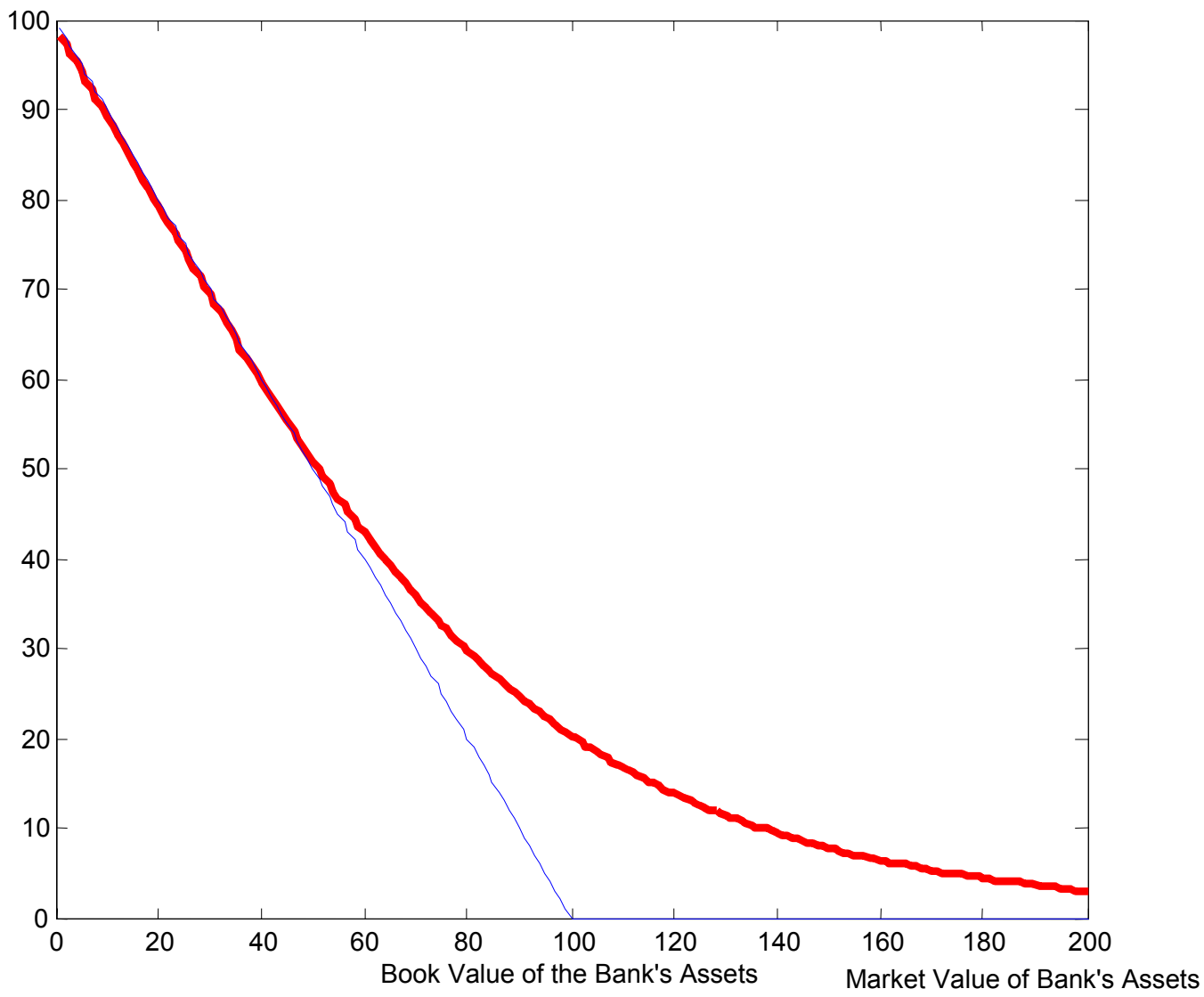


Figure 2

GOVERNMENT'S EXPOSURE TO THE GUARANTEE (HEDGE RATIO)

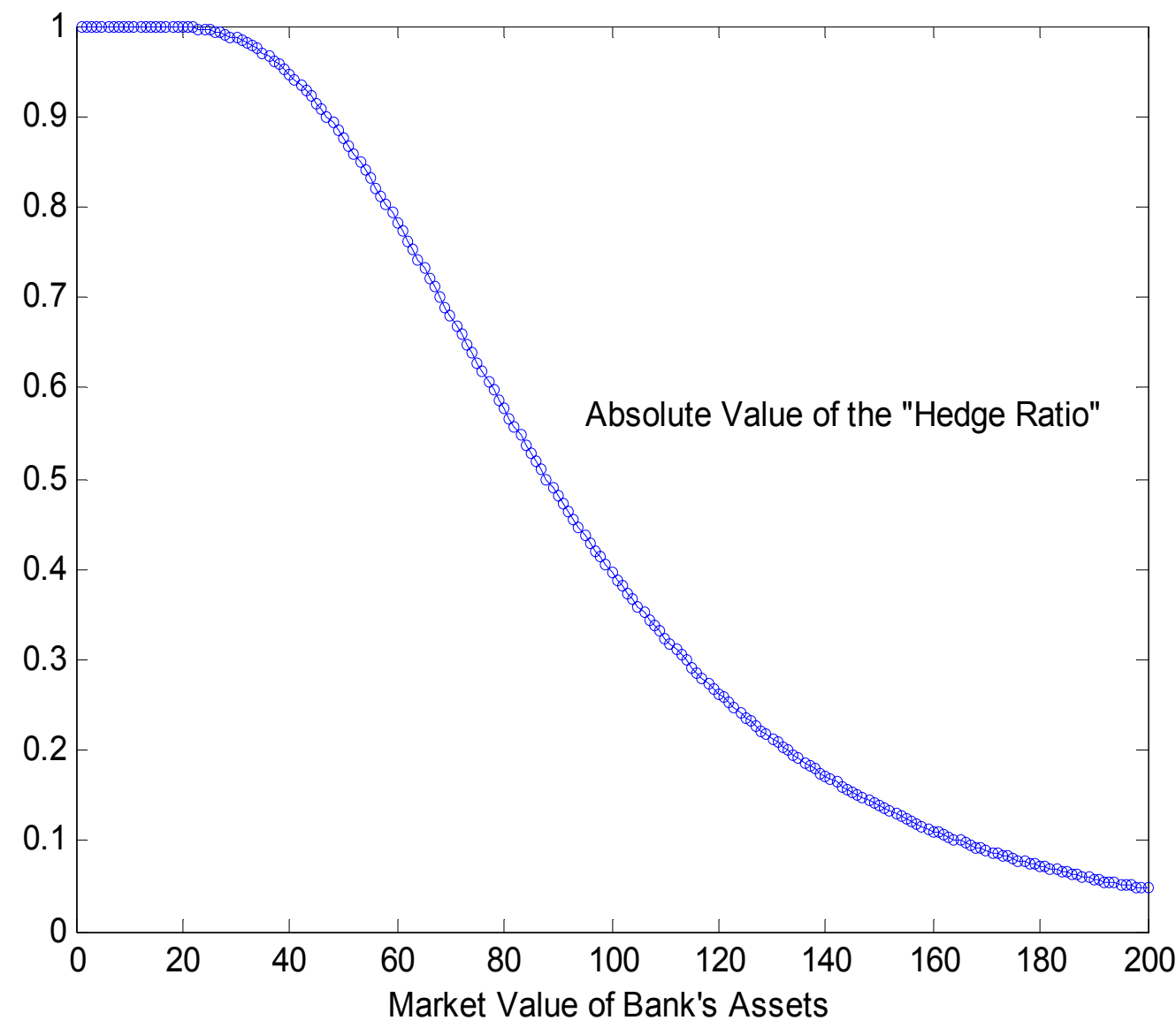

Source: Gray, Merton and Bodie (2002).

\subsection{The non-linear transmission of risk from corporate balance sheets to the government}

The framework described helps explain how volatility can be transferred in a non-linear way from the corporate and banking sectors onto the government. In the example risk is transferred through the guarantee. Following a negative shock to the corporate sector (for instance following a devaluation in the presence of unhedged foreign corporate debt), the value of corporate assets decline, and the value of the government guarantee to the banks increases in a non-linear way. This is also shown in Figures 3 and 4. 
Figure 3

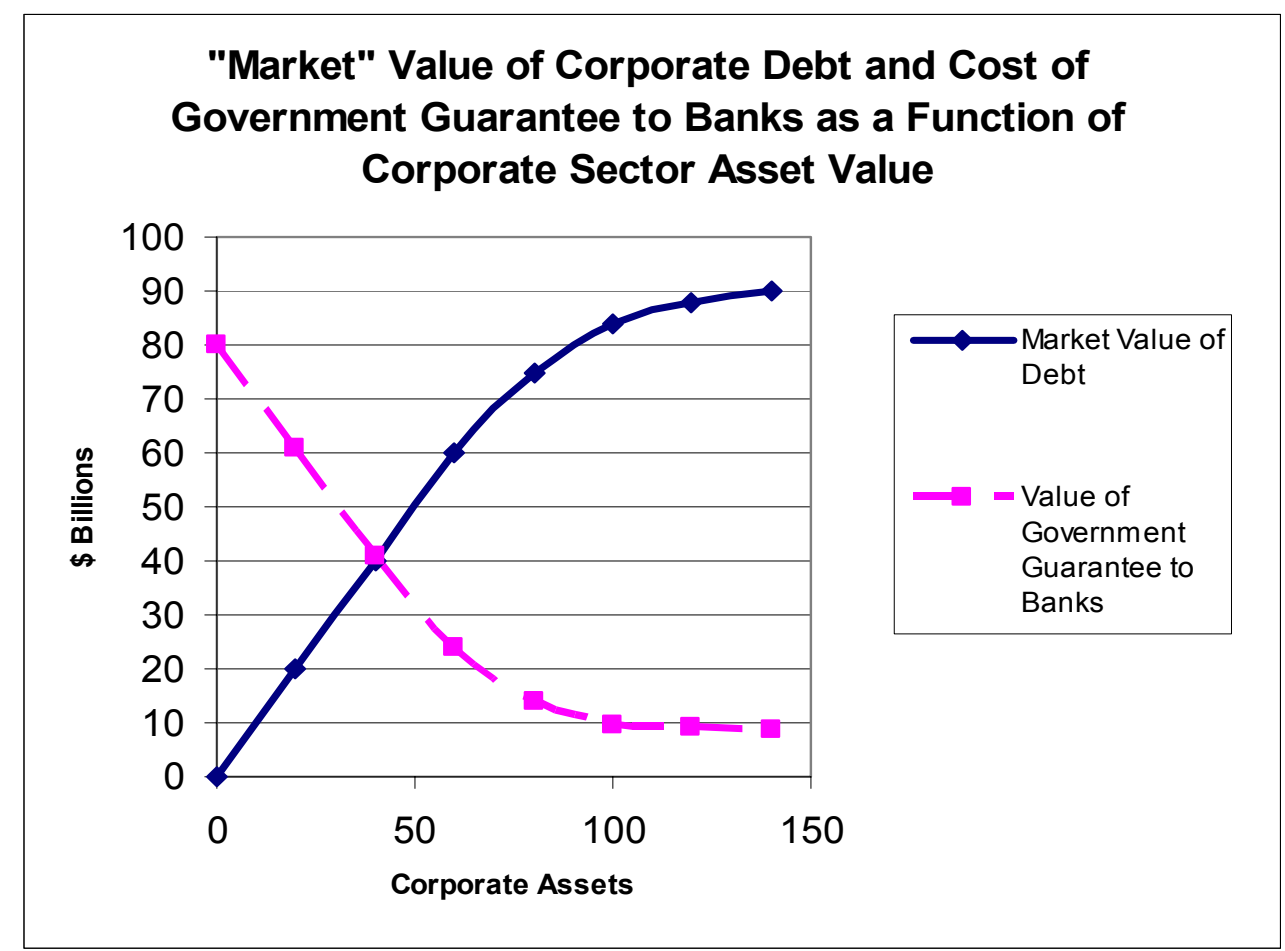

Source: Gray, Merton and Bodie (2002).

Figure 4

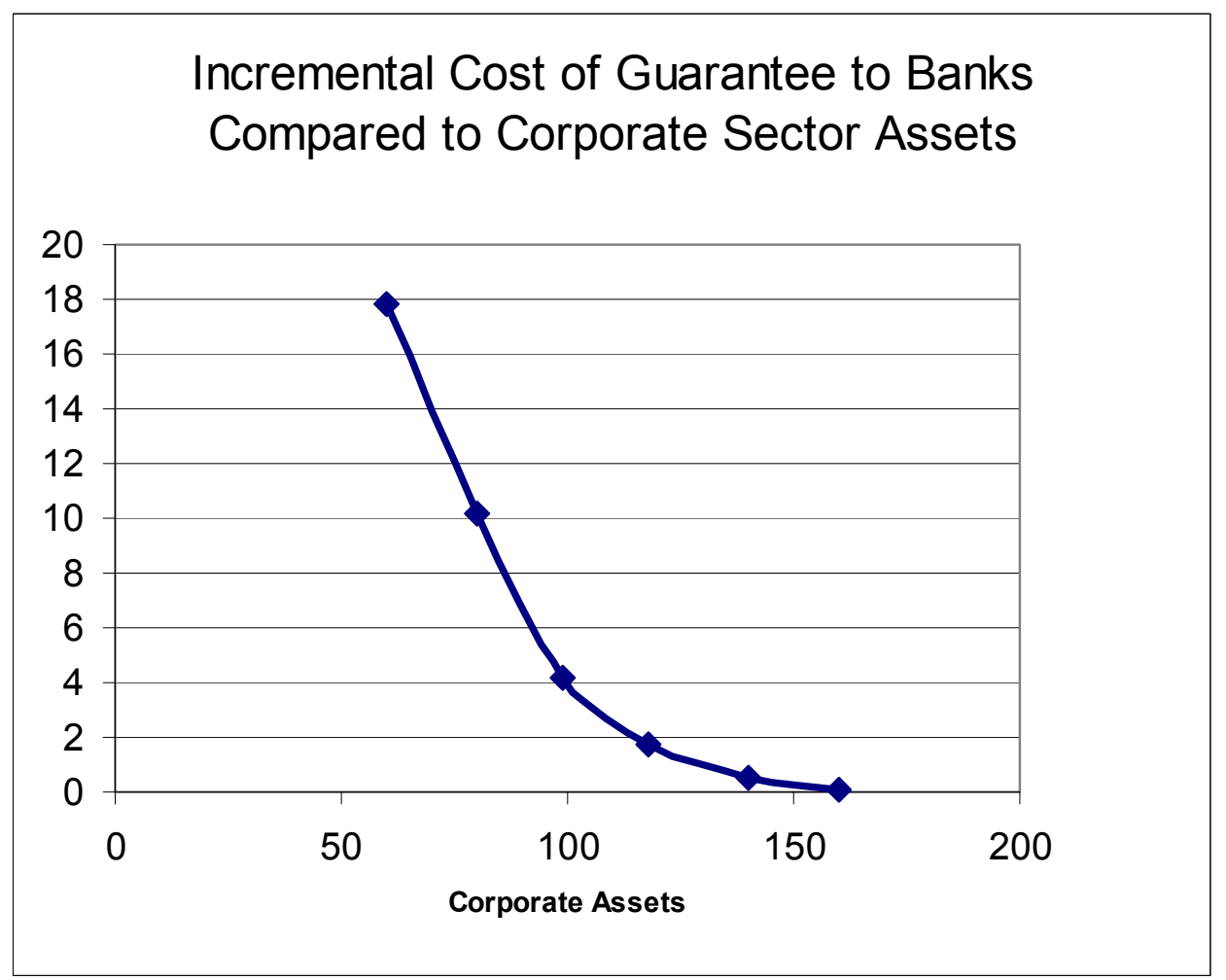

Source: Gray, Merton and Bodie (2002). 


\subsection{Financial guarantees and negative feedback loops}

Financial guarantees can produce negative feedback loops that can trigger severe crises. For instance, rating agencies may react to the information that the value of a government's guarantees has increased by downgrading its sovereign bonds. The downgrade will raise the cost of servicing the public debt and lower the present discounted vale of future budget surpluses. This will lower the value of the government's assets precisely when the value of its liabilities has increased.

\section{Sovereign spreads, macroeconomic volatility and debt maturity ${ }^{16}$}

Countries that issue large amounts of sovereign debt, especially, but not only, in emerging economies, often can only do so by issuing financial instruments with a very short duration. In Brazil, for instance, the duration of two thirds of the entire public debt is currently shorter than 12 months. Thus, when the spreads such sovereigns must pay exceed a certain threshold level, the debt becomes unsustainable. We can think of this threshold level as the one beyond which the country can no longer continue to service its debt without default, or restructuring, or "unrealistically large" adjustments in fiscal variables or in the balance of payments.

Applying options' theory to the analysis of spreads offers a new way to evaluate the risk of default. As illustrated in Box 4.1, spreads depend on the average maturity of the debt, on the level of the risk-free interest rate, on the country's leverage and on the volatility of its assets. These include, if the debt is denominated in foreign currency, the reserves of the central bank plus the (foreign currency value) of the government's fiscal assets, that is the present value of residual fiscal surpluses and other assets.

Consider, as an example, the effect of a shock that both lowers the value of a country's assets and raises their volatility. This could happen, for instance, following a shock that lowers 
the relative price of a commodity in which a country specialises, and increases its volatility. ${ }^{17}$ As shown in Figure 5, the combination of a lower value of domestic assets and a higher volatility can produce a very large increase in spreads, due to the non-linearity in the relation between spreads and asset values.

The relations shown in Figure 5 differ from the arithmetic commonly used to evaluate debt sustainability in two respects:

1. the standard sustainability calculation considers the value of a country's assets - and how this changes, for instance following a devaluation--but fails to realize that changes in volatility also shifts default probabilities, and both affect bond spreads for a given value of a country's assets;

2. the standard computations also fail to realize that the relation between spreads and underlying supporting asset values is non-linear and convex. ${ }^{18}$ In contrast, the optionsbased model provides a structural specification of the non-linear relation between the value of the guarantee and the asset values and their return volatilities.

\footnotetext{
${ }^{16}$ The conceptual framework of the section was first presented in Dale Gray $(2001,2002)$ and in Gray, Merton and Bodie (2002).

${ }^{17}$ Caballero (2003) discusses the effects such a shock in the context of Chile in the mid-1990's, when a fall in the relative price of copper worsened the country's terms of trade.

${ }^{18}$ For a rare recognition of this point in the literature of financial crises, see Fischer (2002).
} 
Figure 5

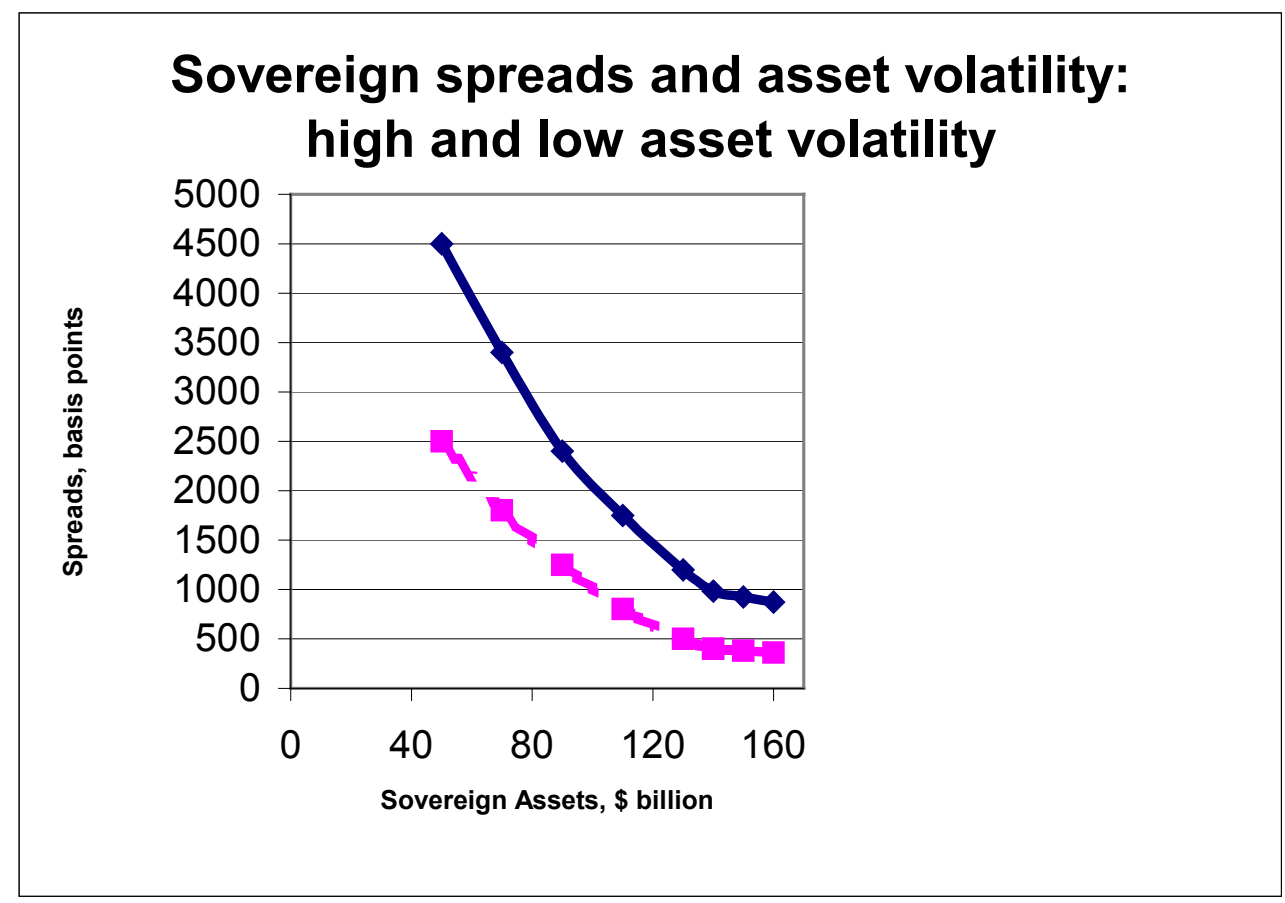

Source: Gray, Merton and Bodie (2002).

The relation between volatility and sovereign spreads is perhaps suggested in the April 2002 World Economic Outlook (IMF 2002, p. 66). The WEO reports various measures of macroeconomic volatility: the standard deviation of GDP, of government revenues and spending, of the terms of trade and the real exchange rate for different groups of countries. Along with these data it shows the frequency of debt-related events, defined as the number of defaults or rescheduling per country group in each period. The data shown in the WEO are reproduced in Table 7. During times of relatively high macroeconomic volatility the frequency of debt events increases. Advanced countries show, on average, less volatility and no defaults. When volatility in advanced countries increased, as in the 1970s' and ' 80 s, compared with the 1990's, it had little effect on the number of defaults because advanced countries start from such 
a high level of assets relative to their debt—which is consistent with the non-linear relation between sovereign assets and spreads shown in Figure 5.

For the purpose of our discussion here, consider a simple model (we outline such a model in Box 4.2) in which future flows of payments to a country's assets are proportional to GDP. If we posit further that flows to the assets are proportional to GDP, and expected future GDP is proportional to current GDP, then expected future cash flows would be proportional to current GDP. The volatility of a country's assets will thus be proportional to the volatility of GDP, and spreads will on average be higher in countries in which GDP volatility is higher. The data shown by the WEO IMF hint at this relation, but fail to recognize the effect of the non-linearity in the relation between spreads and volatility. 
Table 7

$\underline{\text { Output Volatility and Debt Events }}$

\begin{tabular}{|c|c|c|c|c|c|c|}
\hline & Default & \multicolumn{5}{|c|}{ standard deviation of: } \\
\hline & & $\begin{array}{l}\text { GDP } \\
\text { growth }\end{array}$ & $\begin{array}{l}\text { Government } \\
\text { Revenues } \\
\text { percent gdp }\end{array}$ & $\begin{array}{l}\text { Government } \\
\text { Expenditure } \\
\text { percent gdp }\end{array}$ & $\begin{array}{l}\text { Terms } \\
\text { of } \\
\text { Trade }\end{array}$ & $\begin{array}{l}\text { Real } \\
\text { Exchange } \\
\text { Rate }\end{array}$ \\
\hline \multicolumn{7}{|l|}{$1971-80$} \\
\hline Latin America & .44 & 3.8 & 3.2 & 13.4 & 33.6 & 6.6 \\
\hline Emerging Asia & .25 & 2.9 & 1.8 & 8.5 & 14.1 & 5.2 \\
\hline $\begin{array}{l}\text { Advanced } \\
\text { economies }\end{array}$ & - & 2.5 & 2.6 & 4.4 & 17.6 & 2.5 \\
\hline \multicolumn{7}{|l|}{$1981-90$} \\
\hline Latin America & .89 & 4.9 & 3.8 & 16.5 & 27.4 & 39.2 \\
\hline Emerging Asia & .13 & 2.9 & 2.0 & 10.3 & 7.7 & 24.8 \\
\hline $\begin{array}{l}\text { Advanced } \\
\text { economies }\end{array}$ & - & 2.5 & 1.1 & 5.3 & 7.2 & 6.2 \\
\hline \multicolumn{7}{|l|}{$1991-00$} \\
\hline Latin America & .33 & 3.7 & 2.2 & 7.9 & 8.7 & 18.0 \\
\hline Emerging Asia & .25 & 4.1 & 1.8 & 8.3 & 5.9 & 8.7 \\
\hline $\begin{array}{l}\text { Advanced } \\
\text { economies }\end{array}$ & - & 2.1 & 1.0 & 7.2 & 3.7 & 5.9 \\
\hline
\end{tabular}

$\left(^{*}\right)$ Number of defaults or reschedulings per country group

Source: IMF (2002) p. 66. 
Finally, note that a relation similar to that shown in Figure 5 holds for different values of the average duration of the debt, for a given level of asset volatility. In Figure 6, as the average duration of the debt falls from 1 year to 6 and to 3 months, spreads are higher for any given value of the country's assets.

Figure 6

Sovereign spreads and debt duration

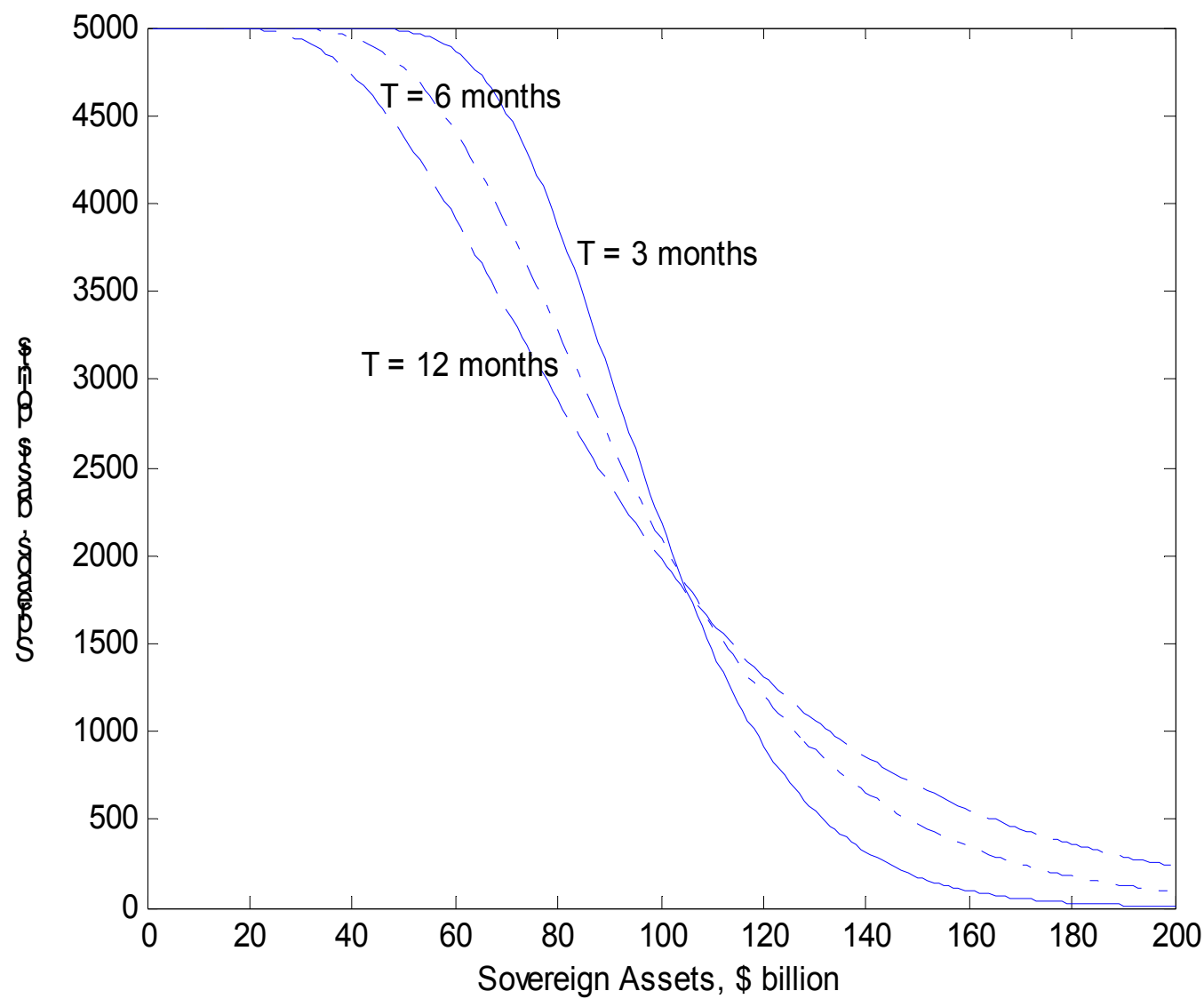

Box 4.1: $\quad$ Using option theory to compute sovereign spreads

Consider a firm with risky assets $V$, which are financed by equity, $S$, and zero-coupon debt with face value $F$, maturing at $T$. Debt is risky: the risk is related to the probability that at 
time $T$ the value of the firm will be smaller than $F$ and the expected recovery amount in the event of default. Thus, at time 0 , the value of the firm's debt, $B_{0}<F e^{-r T}$, i.e. the promised yield to maturity on the debt is higher than the risk-free rate $r$. This defines the yield spread that compensates bondholders for the default risk they bear.

To determine the value of this spread we shall consider, as above, the identity, in value, between the risk-free loan and the combination of a risky loan plus a guarantee. By purchasing a put option on $V$, with strike price $F$, the lenders could completely eliminate the default risk and convert the risky corporate loan into a risk-free loan with face value $F$. If the risk-free rate is $r$, then:

$$
B_{0}+P_{0}=F e^{-r T}
$$

The Black-Scholes model (assuming its assumptions are satisfied) gives us the value of this (put) option: ${ }^{19}$

$$
P_{0}=-N\left(-d_{1}\right) V_{0}+F e^{-r t} N\left(-d_{2}\right)
$$

where $N($.$) denotes the cumulative standard normal distribution, and$

$$
\begin{gathered}
d_{1}=\left[\ln \left(\frac{V_{0}}{F e^{-r T}}\right)+1 / 2 \sigma^{2} T\right] \frac{1}{\sigma T^{1 / 2}} \\
d_{2}=d_{1}-\sigma T^{1 / 2}
\end{gathered}
$$

\footnotetext{
${ }^{19}$ See Merton (1994, 1997). For a recent book explaining these concepts applied to credit risk, see Crouhy, M., D. Galai and R. Mark (2001).
} 
where $\sigma$ is the standard deviation of the return on the firm's assets. As Crouhy et al. (2001,p. 364) show, the formula has intuitive interpretation in the special case when there are no risk premiums on any asset--a so-called "risk-neutral" equilibrium world. ${ }^{20}$

Re-writing the value of $P_{0}$, as:

$$
P_{0}=\left[-\frac{N\left(-d_{1}\right)}{N\left(-d_{2}\right)} V_{0}+F e^{-r T}\right] N\left(-d_{2}\right)
$$

we observe that the premium on the put option can be decomposed into two terms:

. the discounted expected recovery value of the loan, conditional on $V_{T} \leq F$. This is the absolute value of the first term in parenthesis;

- the current value of a risk-free bond paying $F$ at time $T$. This is the second term in parenthesis.

Hence the sum of the two terms inside the brackets yields the (risk-neutral) expected shortfall, in present value terms, conditional on the firm being bankrupt at time $T$. The final factor is the (risk-neutral) probability of default, $N\left(-d_{2}\right)$. The product of the default probability times the expected shortfall determines the premium for insurance against default.

The same expressions can be used to compute the default spread, that is, the difference between the yield to maturity on the risky loan, and the risk-free rate. This is:

$$
-1 / T \ln \left(N\left(d_{2}\right)+\frac{V_{0}}{F e^{-r T}}\right) N\left(-d_{1}\right)
$$

\footnotetext{
${ }^{20}$ A key characteristic of the option-pricing methodology for pricing risky debt that makes it attractive to practitioners is that it does not require estimates of the expected returns on any assets. Indeed, as a computational device, one can value options or risky debt "as if" there were no risk premiums. See Cox and Ross (1976). Hence, the jargon term "risk-neutral" valuation is used to describe this pricing approach. Since the actual expected return of the firm's underlying assets is never used in the pricing formula, the actual probability of default and the actual expected recovery rate are not deducible from bond prices or the formula. Only "risk-neutral" probabilities can be so deduced. If the assets of the firm have a positive risk-premium and thus an expected return greater than the risk-free rate, then the "risk-neutral" probability of default will give a biased-high estimate of the actual probability of default.
} 
The spread is a function of the firm's leverage ratio $\frac{F e^{-r T}}{V_{0}}$, of the volatility of the underlying assets, and of the maturity of the debt $T$. Note that, as volatility and leverage rise, the spread increases in a non-linear way-exactly as in the case of the guarantees discussed in the previous section.

Box 4.2: A fall in output can lead to a reduction in the value of a country's sovereign assets.

The ability to tax is typically a government's most valuable asset. ${ }^{21}$ Thus the sovereign assets of a country include, along with physical assets, the present discounted value of future budget surpluses (i.e. the governments' taxing capability minus those government expenditures that will not be cut to accommodate foreign debt distress). We can therefore express the net sovereign assets of a country as:

$$
(\text { Net Assets })_{0}=A_{o}+\int_{0}^{\infty} e^{-k t} E_{0}[b s(t)]-B_{0}
$$

where $A_{0}$ represents the value, at time 0 , of the physical assets controlled by the government and $B_{0}$ the stock of public debt. $b s(t)=\tau_{t}-g_{t}$ is the primary budget surplus, that is tax revenue minus essential government expenditure, net of interest payments, at time $t$, measured in constant dollars as of time $0, E_{0}$ is the expectation operator, conditional on information at time 0 and $k$ is the real risk-adjusted discount rate, assumed to remain constant over time. $b s(t)$ is assumed proportional to the level of the country's output at time $t: b s(t)=a \cdot y(t)$. If we further assume that shocks to GDP are persistent, that is $d y=\alpha y d t+\sigma y d z$, the value of a country's sovereign

\footnotetext{
${ }^{21}$ Except where large amounts of the country's assets are directly owned by the government, as for example in the Middle East.
} 
net assets will be linearly related to its current level of output, $A_{0}+a y(0) /(k-\alpha)-B_{0}$

The above equation assumes that the real cost of debt remains constant over time. Sovereign spreads, however, as discussed above, increase (non-linearly) when the value of sovereign assets falls. Thus the increase in sovereign spreads induced by a fall in output will be amplified, because lower output, for a given spread, reduces net sovereign assets, and lower net assets raise spreads and thus the cost of debt, which in turn reduces net sovereign assets. This is another instance of the negative feedback loops discussed in section 3.5.

\section{Observations for the correct evaluation of a country's exposure to risk and for the design of prudential rules for financial institutions and their shareholders}

As discussed at length in Gray, Merton, and Bodie (2002), explicit recognition of the chain of financial guarantees offers a rich framework for analyzing the risk exposure of a country. The main benefit comes from the ability to correctly assess dynamically the transfer of risk across sectors. Here are a few examples:

. distress in the corporate sector can be transmitted to the financial sector, e.g. following a change in commodity prices;

- distress in the financial sector can be transmitted to the government, e.g. through the government guarantee of bank deposits;

- sovereign distress or default can be transmitted to the private sector, e.g. through the increase in spreads. The same happens following a devaluation, which can raise firms' leverage and unbalance the balance sheets of financial institutions to the extent that their liabilities are denominated in a foreign currency. 
These issues of risk transmission across sectors were a focus of attention following the financial crises of the late 1990's, whose characteristics did not fit the pattern of the traditional balance-of-payments crises of the previous decade. In this section we try our hand at relating our work to the recent literature on financial crises. The analysis of financial guarantees offers a rich tool for evaluating the extent of a country's exposure to risk and how this changes over time. The importance of this issue is recognized in the traditional literature, but the analogy with the analysis of financial guarantees has not been made. This analogy provides a straightforward tool for analyzing how risk exposure builds up through the economy and eventually cumulates in the government's exposure.

We shall then draw, from the analysis of financial guarantees, some implications for risk monitoring. We shall do this having in mind offering some guidelines for the design of prudential rules for financial institutions and their shareholders.

In the next section we analyze how risk exposures can be controlled, hedged and transferred through the use of derivatives, swap contracts, and other contractual agreements.

\subsection{Balance sheets and financial crises}

Traditionally, international financial crises were characterized as predominantly currentaccount crises. A country would run a large budget deficit, finance it by printing money, with the inflation tax. The currency would, more often than not, be fixed to the dollar-often because the resulting appreciation of the real exchange rate raises real wages. Eventually the trade deficit produced by the overvalued real exchange rate could no longer be financed: reserves dried up, and so did the supply of international loans. What followed were devaluation and a sharp cut in real wages, which in turn helped a recovery of economic activity.

More recent crises, starting with Mexico in 1994-95, and then Asia and Russia in 1997-98 are fundamentally different in that balance-sheet issues are central to the descriptions and almost surely to the propagation of the crisis, as vividly described in Dornbusch (1998): 
"In Mexico's massive earthquake, some years back, many of the splendid new buildings collapsed burying and killing a large number of people in the debris. Without the earthquake they surely would not have crashed, in fact they had graced the skyline for years, monuments to their proud owners and builders. But examination revealed that the concrete had far too much sand and too little of the real stuff. Not surprisingly, under stress they went. That surely was not an accident - the building codes were there, and the inspectors stood by collecting the payoffs for overlooking unsound construction. Just the same has been happening in cross border finance. Emerging market balance sheets stand up in fair weather but under stress they collapse. Vulnerability is the key word; risk is another way of looking at it."

The observation that the origin of many international financial crises lies in the accumulation of risk in balance sheets is central to the recent macroeconomic literature on such crises (for recent statements see Calvo, 2002 and Jeanne and Zettelmeyer, 2002). Understanding the effects of risk accumulation in balance sheets is important because it explains why, in crises of this type, monetary and fiscal policies tend to become ineffective. Banks with weak balance sheets do not react to an increase in central bank money by raising the supply of loans; and if government with a weak balance sheet attempts a fiscal expansion, spreads on government debt issues will go up, which often translate into higher spreads on private-sector borrowing as well.

These observations also underscore Dornbusch's recommendation that: "the right answer to crisis avoidance is controlling risk. The appropriate conceptual framework is value at risk $(V A R)$ - a model-driven estimate of the maximum risk for a particular balance sheet situation over a specified horizon. There are surely genuine modelling issues with the specifics of VAR as has been widely discussed with respect to bank risk models used for meeting BIS requirements (cf. Crouhy et al, 2001). But just as surely there is no issue whatsoever in recognizing that this general approach is the right one. If authorities everywhere enforced a culture of risk-oriented evaluation of balance sheets, extreme situations such as those of Asia in 1997 would disappear or, at the least, become a rare species. 
This literature on international financial crises $^{22}$ recognizes that the implicit guarantees governments extend to banks and, through them, to firms create the potential for greatly weakening government balance sheets. The attention, however, has mostly focused on the reasons why such guarantees exist, rather on the correct measurement of their cost and changing risk exposures. One view (e.g. Burnside, Eichenbaum and Rebelo, 2001), emphasizes government bailouts, which encourage banks to willingly expose themselves to exchange rate risk: it is the government guarantee that makes it optimal for banks to have an unhedged currency mismatch between their assets and their liabilities, and thus transfer the exchange rate risk onto the government. Of course, the strength of that incentive is affected by whether current shareholders will lose their ownership in the event of failure or retain it. Subtler is the view exposed by Caballero and Krishnamurthy (2000) who ask why private borrowers underinsure against country shocks and exchange rate depreciation by contracting foreigncurrency denominated debt. The answer they provide is that under-insurance is a feature of underdeveloped financial markets: if financial markets are well developed, firms have no incentive to take up excessive foreign-currency denominated debt. ${ }^{23}$

The contribution of our paper is in spirit responsive to the Dornbusch recommendation, in that it provides a framework for correctly evaluating the extent of a country's exposure to risk and the changes in that exposure over time.

\subsection{Government exposure to the financial system: computing a country's value-at-risk}

A country's exposure to risk, at any given point in time, results from the risk exposure of each sector in the economy and from the transmission of risk across sectors through financial guarantees. Understanding how a sector's exposure changes when events hit a different sector, and realizing that exposure to risk changes non-linearly, is the main benefit of the financial

\footnotetext{
${ }^{22}$ For an introduction to this literature see Dornbusch (2002). For a review of recent contributions see Feldstein (2003).

${ }^{23}$ For a discussion of these alternative views, see Tirole (2002).
} 
guarantees approach. The approach suggests a new way of thinking at macro risk: describe the economy as a set of interconnected portfolios of assets, liabilities and contingent claims and ask how the values of these portfolios react to external shocks (shocks to fundamentals).

To correctly appreciate the extent of a government's exposure to its financial system, three steps are involved:

a) the traded and non-traded assets of financial institutions, banks in particular, should be systematically marked to market: this is the first step to correctly evaluate the dimension of any existing guarantee;

b) the guarantees extended to financial institutions, whether explicit or implicit, should be openly recognized in the government's balance sheet. Rather than precise rules for governments to consider adopting, we frame a general orientation towards helping markets appreciate the extent of the guarantees.

c) a government's exposure to its domestic financial institutions-incurred through the outstanding guarantees to these institutions - explicit or implicit-increases more than proportionately with changes in the weakness of the balance sheet of these institutions. The additional liability transferred on the government's balance sheet by a 10 percent shock to the capital of firms is larger the lower is that capital to start with. If the balance sheets of corporations and financial institutions are weak when the economy is weak - as it is generally the case - then it is precisely when tax revenue is low, and the cost of debt service high because sovereign risk has increased, that the value of the guarantees will be particularly high. This observation offers a powerful argument for diversification of the government exposure to local shocks, for instance by swapping tax revenue - an issue we take up in next section of the paper.

As noted in Merton (2002, p.66-67):

"A prospective application of modern financial technology by government is the measurement and management of country risk.... 
A non-traditional approach to address the performance issue and its implication for evaluating policy is to apply the technology of a well-studied problem in risk and performance measurement for investment management and financial firms. This is the problem of configuring all the decomposition and reintegration of risk-factor exposures that must be determined within a financial institution before the aggregate risk measures such as value-atrisk (VAR) can be applied. I believe that this technology, if properly adapted, can be used to measure country risk exposures

. this is structurally the same problem faced in the risk measurement of non-traded assets and liabilities in financial institutions. In short, it is like the challenges of extending the VAR and stress-testing concepts to include the domain of non-traded assets and liabilities. But as with the application to financial institutions, I see this as a tough engineering problem, not one of new science ... we know how to approach it in principle and what we need to model, but actually doing it is the challenge.

As with conventional private-sector applications, the country risk exposures give us important information about the dynamics of future changes that cannot be inferred from the standard "country" accounting statements, either the country balance sheet or the country income or flow-of-funds statement.

As we discover with more conventional applications of risk management systems, once we can measure the risk exposures we have, it is difficult to resist exploring whether we could improve economic efficiency and risk sharing by changing those exposures.

With the developed countries, Japan and EMU Europe in particular, and the emerging ones both working on major changes in their financial systems, this may be an especially opportune time to explore country risk management."

Gray (2001 and 2002) has implemented this framework to build multi-sector economicvalue balance sheets of countries. Such balance sheets explicitly compute to what extent the values of financial guarantees change as assets and liabilities change and thereby provide ways to capture changing risk exposures as well as changing values (See also Gray, Merton and Bodie, 2002). This approach goes well beyond the simple recognition, pointed out in Blejer and Shumacher (2000), that the correct measure of a central bank's exposure to risk should take into account the option value of any foreign-exchange derivative contracts the bank might have entered into.

For instance, using data for Thailand at the end of 1996, Gray (2001) has estimated the value of the Thai government's exposure through its implicit financial guarantees. At 33 Baht per 1 U.S. dollar (the December 1996 exchange rate was 25.6 Baht per dollar) the government exposure was short a put option whose value was less than 10 percent of GDP, provided equity prices remained unchanged and liquidity, measured by the willingness of lenders to roll-over or 
refinance Thai USD loans, also remained unchanged. If equity prices declined 50 percent and liquidity were reduced, devaluation beyond 33 Baht per dollar would have raised the value of the implicit put option to 30-50 percent of GDP - a clear implication of the power of the nonlinearity in option values. By December 1997 in the crisis, the exchange rate reached 47 Baht per dollar and equities had lost 60 percent of their pre-crisis value.

\subsection{The valuation of banks' assets}

Bank loans should be valued on a systematic and ongoing basis taking into account the borrowers' ability to repay. There are several appropriate ways to do this, depending on circumstances. If the borrower issues debt, and the bonds are liquid, then use those marked-tomarket prices to value the loans. If its credit rating is known and frequently updated, so-called matrix pricing based on rating spreads can be applied. Financial market prices such as the underlying firms' equity prices can also be used to provide up-to-date estimates of the value and risk sensitivities of the loans using models like the one developed in Merton (1974): For empirical tests of the model, see Kealhofer (2003) and for its real-world applications, see www.moodyskmv.com and http://www.creditgrades.com. The fact that these alternative methods often produce different valuations should not be a reason for inaction.

Standard accounting rules for marking down book values are subject to considerable management discretion. It is interesting to note that the valuation method based on historical cost commonly used is the least effective precisely at times when investors and overseers need the assurance of realistic and current valuations. When uncertainty grows, investors want a system that reflects asset values in the changed market environment, not book-value valuation, which rarely produces a change in price.

Even if the loans are appropriately marked to market, there is an issue on how to measure the future risk exposure. The amount of money that one can reasonably expect to lose as a 
result of a default over a given period is a bank's "expected risk exposure". ${ }^{24}$ The expected loss will depend on (i) the amount exposed to credit risk; (ii) the probability of counter-party defaulting, (iii) the recovery rate. The problem of measuring potential credit losses lies in finding the best way of estimating these variables. With respect to (ii) and (iii) institutions should develop techniques to compute the default rate path and the recovery rate path, and distributions around these paths estimated by examining those distributions at specific points in time in the future. As for the recovery rate one could use the recovery rate distribution as derived from surveys of recovery rates of senior corporate bonds that have defaulted. This analysis produces estimates of future recovery rate distributions that vary as a function of time. Just like default rate distributions they do not typically follow a normal probability density function. Finally, the distribution estimates of (i) - (iii) are to be combined to produce an overall assessment of the expected risk exposure. ${ }^{25}$

As for derivative instruments, starting with 2001-Q1 the FASB (Financial Accounting Standards Board) requires most U.S. companies to adopt rule FAS 133 "Accounting for Derivative Instruments and Hedging Activities". This means that derivatives or hedged positions, even those embedded in contracts, should be reported on the balance sheet using their fair value (marked-to-market). Prior to this ruling derivative financial instruments were not recorded on the balance sheet. ${ }^{26}$

${ }^{24}$ See e.g. Crouhy et al. (2001). p. 551
${ }^{25}$ A step in this direction is the CreditRisk + model developed by Credit Suisse Fin
described in Credit Suisse (1997). Valuation of risky debt does not necessarily requir|
factors or a discount rate, as in Merton (1974).
${ }^{26}$ Rule FAS 133 is currently under review, see http://www.fasb.org/project/133. FAS
plays a prominent role for initial recognition or ongoing valuation are:
\begin{tabular}{|l|l|}
\hline \hline FAS regulation number & Subject \\
\hline \hline FAS 115 & Valuing equity investments \\
\hline FAS 123 & Stock-option accounting \\
\hline \hline FAS 133 & Hedging derivatives \\
\hline FAS 141 & Business combinations \\
\hline \hline FAS 142 & Purchased intangibles \\
\hline \hline FAS 143 & Asset retirement obligations \\
\hline \hline Interpretation 45 (affects & Guarantees \\
\hline FAS 5, 57, and 107) &
\end{tabular}




\subsection{Can equity and and/or subordinated debt substitute for risk monitoring?}

The previous analysis suggests that careful monitoring of all the items on and off the balance sheet is essential for proper risk management. How strong are the off-balance sheet guarantees in the face of an unexpected fall in the correctly computed value of the bank's assets? Can equity be a substitute for risk monitoring? Shareholders may be reluctant to commit large quantities of equity capital because of the agency costs related to this strategy and because of its unfavourable taxation. Subordinated debt, provided it is really junior to the depositors' claims, could be preferable to large equity commitments. However, its subordinated nature can be more apparent than real. In the United States, its economic subordination need not be followed strictly by courts within the context of Chapter 11 proceedings. Therefore, neither equity capital nor subordinated debt is a substitute for careful risk monitoring of assets' values. Just as important is the marking to market of the liabilities and more specifically the monitoring of the market prices of the bank's equity and subordinated debt, reflecting in effect the value of the collateral guarantee by the shareholders. $^{27}$

\subsection{Hedging macro risks}

The approach to risk management discussed above has implications for the banking industry in emerging markets in which there is a high degree of macro risk and correlation amongst all assets' values. In this context, a common sense rule of asset diversification would suggest that an emerging-market bank that invests part of its assets in domestic government bonds increases its exposure to local macro shocks: the value of government bonds will be low precisely when the value of the loan book is low. Therefore, in such economies, banks should hedge the exposure of their loan book more than they would normally do in the context of 
advanced economies, for example investing in non-domestic assets-be they bonds or otherwise.

This issue came up during the recent crisis in Turkey. Turkish banks, as most emerging market banks, own large fractions of the domestic public debt: the general macroeconomic crisis which depressed the value of the loan books also brought the Turkish government close to defaulting on its bonds. Also the value of other assets in the banks' balance sheets and their own equity value collapsed, resulting in a credit crunch and a further fall in the loan book values. On the basis of our previous analysis one would conclude that lack of proper monitoring and of proper risk diversification amplified the crisis. Our guarantee-based approach to risk management would have suggested the need for additional equity capital for the banks to continue their operations. Certainly the private sector had no incentives to provide such equity, which eventually came in the form of a blanket government guarantee on all bank deposits. The actual value of this off-balance sheet equity was itself dependent on the IMF's financing and on the government's successful fiscal retrenchment effort. Some G7 countries had advocated default on all public debt, and therefore also on the government guarantee, as a way to relieve Turkey's budget from the burden of interest payments. It is now clear that such a course of action, destroying both on-balance sheet and off-balance sheet banks' equity, would have caused a bank run and a worsening of the crisis.

\subsection{Foreign ownership of an emerging country's banks}

We have just seen how in small emerging market economies especially the value of the government guarantee to the banking industry is highly negatively correlated with the value of the banks' loan assets. When the bank's assets decrease because of a macroeconomic shock, there is an increase in the government's liability from the guarantee because the expected risk

${ }^{27}$ On this point see Bodie and Merton (1993) and Merton and Bodie (1992). 
exposure is now higher, unless the bank raises adequate additional capital. This requires prompt action by the government or by the shareholder. ${ }^{28}$ Unfortunately, when a serious crisis erupts, a statement by the government that it will stand by its guarantee has less credibility, while shareholders lack the incentive to provide additional capital. Incidentally, the same shareholders of the bank may have less new investment capacity, having invested in other sectors of the same economy.

Spain's direct investment in Argentina provides an example. The "cultural proximity" between the two countries resulted in direct investments being cumulated. Some large Spanish banks directly owned Argentinean banks, while at the same time also owning (often indirectly through their shareholding in Spanish companies) Argentinean firms operating in the industrial and service sectors. When the country's economy collapsed the value of those firms also collapsed. Spanish banks had anticipated this event by creating, on their balance sheet, loss reserves to be used to write off their investments both in the banks and in the industrial and service companies they owned - which in the event they did. Following these large write-offs they were either unwilling or unable to infuse additional equity capital in the Argentinean banks they owned, thus accelerating their demise and shifting upon the government the responsibility for guaranteeing the bank's liabilities. ${ }^{29}$

It has rightly been suggested that especially governments in emerging markets perform risk audits of their assets and liabilities using VAR-like methods in their assessments. We recommend that they should also periodically reassess the value of the guarantee they are implicitly and explicitly giving to the banking system and measure the expected risk exposure. There would arise a strong case for prudential regulation requiring the banks operating in these countries to sell or to diversify their loans portfolios into other countries' assets through securitizations, credit default swaps and credit derivatives. Furthermore, as Spain's example

\footnotetext{
${ }^{28}$ Such action, because of the non-linear relation between the price of the option and the value of the loan, must be of a bigger size than what is suggested by the static comparison of the two values in the new state.
} 
shows, the foreign shareholders of the banks should comply with similar rules especially if they are banks themselves.

\subsection{Guarantees and governments' financial policies}

A weakening of the domestic economy affects a government's balance sheet in two ways. On the side of liabilities, the value of the implicit guarantee that the government provides to local banks increases - because, when the economy weakens, the value of the banks' loans is likely to fall. The weakening of the economy is also associated with a fall in tax revenues: this in turn lowers the value of the government's assets, as discussed in Box 4.2. ${ }^{30}$ The two effects interact, because the percentage increase in the liability transferred onto the government's balance sheet caused by, say, a 10 percent decline in the capital of firms, and thus in the value of bank loans, is larger the smaller is that capital to start with.

This analysis suggests four remarks:

i. Given the amount of short-term liabilities of the banking system in an emerging market country, given an estimate of the probability of default and of the recovery rate distributions (as discussed in Section 5.2 above), it should be possible to compute that level of the government's assets that is necessary to provide a guarantee to those short term liabilities and how this should be adjusted following changes in the value of the loan book.

As shown in Box 4.2, the PV of future available budget surpluses (i.e. the governments' taxing capability minus those government expenditures that will not be cut to accommodate foreign debt distress) is an important, often the most important, asset

\footnotetext{
${ }^{29}$ Most foreign banks, not only Spanish banks, simply wrote their investments off and failed to invest additional capital when the crisis erupted.

${ }^{30}$ The fall in the government's assets can be even bigger if, as discussed in Box 4.1, the initial fall in the value of assets raises spreads and thus the cost of debt service.
} 
available to a government to support its debt. Therefore, the path of future fiscal variables should be adjusted whenever the value of the guarantees changes. This observation provides a rational for IMF plans which commit countries to a future path of primary surpluses.

ii. The greater is the short-term capital inflow and the consequent domestic credit expansion, the greater is the subsequent risk exposure and, therefore, the greater should be the collateral asset value of the government. Sizeable short-term capital inflows should thus be accompanied by the establishment of formal reserves in the accounting to reflect the higher liabilities. However, as already mentioned, in many countries the government's most important asset is represented by the path of projected budget surpluses: therefore, short-term capital inflows should be accompanied by an increase in the path of projected budget surpluses, which would thus act as reserves.

iii. As we have seen in the case of Argentina, these governments should avoid currency mismatch between the base of their guarantee (the tax revenue) and the risk exposure. Therefore monetary arrangements like fixed exchange rates, and especially currency boards, when they are accompanied by a currency mismatch in the balance sheet of financial institutions are particularly vulnerable.

iv. Private-sector equity can hardly be expected to substitute for the guarantee provided by the domestic government. Private-sector equity is at most a cushion and can hardly be expected to perform the role of a guarantee. In the case of financial intermediaries, equity is a tiny fraction of total liabilities and its value is correlated with the value of the loan book. 
This observation offers a powerful argument for diversification of the government exposure to local shocks, for instance by swapping tax revenue - an issue we take up in section 6 of the paper.

\subsection{Observations on Basel II}

It has been argued (see e.g. Persaud, 2000, Borio et al., 2001 and Reisen, 2001) that Basel II will raise the volatility of private-sector capital flows to developing countries. Basel II retains from Basel I the fixed link between banks' lending and equity, in the form of the fixed minimum capital requirement of 8 percent. Furthermore, risk weights are assessed on the basis of indicators that are pro-cyclical: under the "standardized approach" the external ratings, under the "internal ratings-based approach" the probability of default. It can be argued that both indicators behave pro-cyclically so that the borrowers' risk category worsens and correspondingly their credit spreads widen in bad times, therefore increasing both the probability of further down-grades and of default.

Such negative feedbacks, however, are not the result of regulation per se. If the reason why a country is downgraded (or its default probability, as assessed by the lenders under the "internal ratings-based approach", is changed) is a real value problem, then the larger spreads simply reflect the increase in the amount of risk transferred onto the lenders, or onto the government that is providing the lenders with a guarantee. If instead the problem was just one of liquidity, then neither ratings need change, nor spreads increase.

\subsection{Capital controls}

Institutional environments in emerging market countries may make continuous risk management by governments, banks and banks' shareholders, a rather complex task. More specifically, assessment of risk exposure and prompt response to its changes may be hampered 
by lack of transparency and poor functioning of financial markets, so that governments can neither charge adequate risk-based premiums for their implicit or explicit guarantee, nor monitor properly risk exposure. In such a situation it may be tempting to conclude that the only alternative is restrictions on both the ownership of assets and the issue of liabilities - for instance to avoid the accumulation in banks' balance sheets of currency mismatches that cannot be diversified away.

Indeed, there are those who argue that some of the capital controls and of the distortions present in many emerging markets during the 1980's, can be rationalized as responding to that motivation. The large variety of capital controls in the various countries makes it hard to draw any generalization. Indeed, restrictions on capital outflows were hampering in varying degrees just the kind of asset diversification that we have seen to be beneficial especially when there is concentrated country risk. However, by the same token, these restrictions were also applied to banks' domestic liabilities, so that bank runs to shift assets outside the country were difficult, and governments could always use inflation to make good on their guarantee. In general, tight controls on capital outflows discouraged future capital inflows, serious currency mis-matches were rare, and most importantly governments were guaranteeing deposits that were denominated in the same currency as the domestic tax revenue base. That was not the case in Argentina, where ten years after financial deregulation the government was called to guarantee U.S.-dollar-equivalent bank deposits while the peso-denominated tax revenue base was shrinking and the exchange rate was depreciating.

Emerging countries' financial markets were certainly far from being efficient during the 1980's. Removing controls and asset restrictions were viewed by many as a fundamental step to promote growth and efficiency. But this well-intended action may have had the unanticipated and unintended consequence of reducing the intensity of monitoring of 
government-insured institutions without providing a fully offsetting protection for the guarantor. $^{31}$

\section{Managing risk to reduce financial fragility}

Many emerging countries have large concentrated exposures to specific industries — often the result of the domestic economy being relatively specialized. Table 8 provides one example. The data document Taiwan's' exposure to electronics, which is large both relative to the country's exports and to its value added.

Table 8

Taiwan: Export shares and sectorial shares in manufacturing value added (2000)

\section{Shares in manufacturing value added electronics products and components $\quad 35.6$ of which \\ - semiconductor devices $\quad 15.0$ \\ - communications equipment $\quad 7.2$ \\ - computing and data processing equip. $\quad 30.2$}

Shares of total exports

electronics 42.4

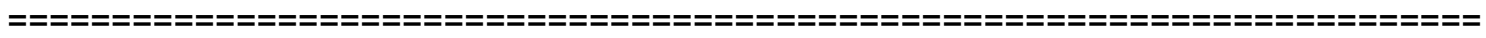

Source: Republic of China, Monthly Bulletin of Statistics, April 2002.

Industrial policy to encourage the domestic development of other industries has traditionally been the way many countries have tried to diversify their risk exposure to specific sectors. The common policy instrument was public investment, often through state-owned enterprises. The sub-optimality of such policies is obvious, as investment is often directed towards sectors in which the country has no special comparative advantage. Furthermore, once

\footnotetext{
${ }^{31}$ It is the nature of policy changes in general that they will have unanticipated consequences. See R.K. Merton $(1936,1989)$.]. It does not follow, however, that reinstitution of capital or asset controls is the answer.
} 
the investments are made and considerable numbers of citizens are working in those newly created domestic industries, it becomes very difficult to reverse policy.

Diversification through capital mobility is one obvious alternative. Financial markets allow a country to diversify its exposure to specific sectors, while exploiting its comparative advantage. Taiwan, for instance, could trade domestic stock ownership of its domestic electronics firms for a world-diversified portfolio of equities. Singapore, through the Government Investment Corporation and related funds, appears to have taken significant steps to diversify through foreign securities holdings. In general, however, this solution runs against at least three obstacles: it is inflexible (once done, deep foreign ownership of domestic shares is not easily reversed or changed); it creates incentive problems, as fear of expropriation of foreigner-held shares in domestic firms is always a possibility; it often runs against local political constraints such as the belief that the country's "best" assets were sold to foreigners at too low a price.

Swap contracts and other derivative instruments provide an appealing alternative. Swaps allow a country to diversify risk without shifting the ownership of assets. For example, a country could impose tight capital controls, limit foreign ownership of domestic firms and still reduce its exposure to risk: swap contracts do not require the transfer of ownership of the underlying asset. Risk diversification through derivative instruments is obviously more flexible than diversification through the transfer of assets. ${ }^{32}$

\footnotetext{
${ }^{32}$ Caballero and Panageas (2003) suggest that Chile could eliminate most, if not all, of its deep recessions by embedding into its external bonds a long put option, yielding US\$ 6-8 billions when the price of copper falls by more than two standard deviations for a semester or more. They estimate that such insurance, if fairly priced, might cost US\$ 500 millions (lump sum). Caballero (2003) argues, however, that currently "there is no natural market for holding such an instrument, and the corresponding derivatives markets would not suffice to cover the position of the writer of the option. "Even in the best emerging economies, he argues, aggregate risk management is being done with stone-age instruments and methods. "He thus concludes suggesting that the IMF has a key role to play here in resolving this impasse and becoming a catalyst for such a development. He proposes that "the IMF creates a new Contingent-Markets Department which should have three primary tasks: (i) To help identify each country's contractible contingent basis and develop the corresponding contingent bonds; (ii) To help create and regulate contingent market CDOlike funds; (ii) To help design a macroeconomic policy framework consistent with the insurance mechanism developed for the country, and monitor its fulfillment.
} 
The analysis of financial guarantees offers a rich framework for comparing alternative ways to control risk. In the remaining paragraphs of this section, we discuss how derivatives (swaps) can be used-and the extent to which they are used in practice-to limit the accumulation of risk and thus reduce a country's financial fragility.

Box 6.1: Diversifying Taiwan's exposure to electronics

Consider Taiwan. Call $R_{T}$ the (stochastic) return on Taiwan's GDP and $R_{W}^{E}$ the (stochastic) world return on electronics. Since Taiwan is heavily exposed to electronics

$$
R_{T}=a+b R_{W}{ }^{E}+\varepsilon_{T}
$$

where $\varepsilon_{T}$ is a country-specific component and $b$ is larger the higher the exposure. Let $R_{W}^{S M}$ be the return on a well-diversified portfolio of world equities. Consider a swap agreement where Taiwan pays $\lambda R_{W}{ }^{E}$ and receives $\lambda R_{W}^{S M}$ thus ending up with

$$
R_{T}=a+(b-\lambda) R_{W}^{E}+\lambda R_{W}^{S M}+\varepsilon_{T}
$$

by choosing a value of $\lambda$ sufficiently close to $b$ the country could reduce its exposure to electronics. For $\lambda=b$ Taiwan would be left with the return on the well-diversified world equity portfolio plus an exposure to its idiosyncratic risk $\varepsilon_{T}$.

The swap as described is a "right-way" swap: in bad years, when electronics firms do worse than the world index of other industries, Taiwan is on the receiving end of the swap. It pays when world electronics outperform other industries. The country thus pays only in states of the world where the world industry sectors represented in local firms outperform the world index of other industries, i.e. when the country is relatively economically stronger. 
Swaps can also be used to reduce the overall risk a country faces: Taiwan could hedge its exposure to risk by swapping (a fraction of) its exposure to $R_{W}{ }^{E}$ for the world risk-free rate.

Swapping the return on world electronics for the return on a well-diversified world equity portfolio, or for the risk-free rate, or for a mix of both, Taiwan would remain exposed to the idiosyncratic component of the returns of local firms, $\varepsilon_{T}$. This may be the efficient thing to do from the point of view of local incentives, since $\varepsilon_{T}$ is the only component of the return of local firms on which the country has some control.

In principle, Taiwan could also diversify away the exposure to idiosyncratic risk, by swapping the total return on its domestic portfolio of electronic companies (in effect both $R_{W}{ }^{E}$ and $\varepsilon_{T}$ ) for the return on the world diversified market portfolio. This limiting case would allow Taiwan to eliminate completely its exposure to local electronics firms, thus recreating the same conditions that would prevail if all domestic electronic firms were owned largely by foreign residents and Taiwan invested broadly around the globe. In this extreme case, however, as under too-large foreign ownership of domestic firms, the drawbacks are related to the incentive to expropriate, or the usual agency costs of a non-owner manager.

\subsection{Equity swaps as an instrument to diversify risk Internationally ${ }^{33}$}

In this section we illustrate how an equity swap could enable a small country to diversify risk internationally without violating possible restrictions on investing capital abroad. Suppose that small-country pension funds who already own the domestic equity were to enter into swaps with a global pension intermediary (GPI). In the swap, the total return per dollar on the small country's stock market is exchanged annually for the total return per dollar on a marketvalue weighted-average of the world stock markets. This exchange of returns could be in a common currency, dollars, as described or adjusted to different currencies along similar lines 
to currency swaps. The magnitudes of the dollar exchanges are determined by the "notional" or principal amount of the swap to which per dollar return differences apply.

Without pursuing the details of implementation, we see that the swap effectively transfers the risk of the small-country stock market to foreign investors and provides the domestic investors with the risk-return pattern of a well-diversified world portfolio. Since there are no initial payments between parties, there are no initial capital flows in or out of the country. Subsequent payments, which may be either inflows or outflows, involve only the difference between the returns on the two stock market indices, and no "principal" amount flow.

For example, on a notional or principal amount of $\$ 1$ billion, if, ex post, the world stock market earns 10 percent and the small-country market earns 12 percent, there is only a flow of $(.12-.10) \times \$ 1$ billion or $\$ 20$ million out of the country. Furthermore, the small-country investors make net payments out precisely when they can "best" afford it: namely, when their local market has outperformed the world markets. In those years in which the domestic market under-performs the world stock markets, the swap generates net cash flows into the country to its domestic investors. Hence, in our hypothetical example, if the small-country market earns 8 percent and the world stock market earns 11 percent, then domestic investors receive $(.11-.08)$ $\mathrm{x} \$ 1$ billion $=\$ 30$ million, a net cash inflow for the small country. Moreover, with this swap arrangement, trading and ownership of actual shares remain with domestic investors.

Foreign investors also benefit from the swap by avoiding the costs of trading in individual securities in the local markets and by not having the problems of corporate control issues that arise when foreigners acquire large ownership positions in domestic companies. Unlike standard cash investments in equities or debt, the default or expropriation exposure of foreign investors is limited to the difference in returns instead of the total gross return plus principal (in our example, $\$ 20$ million versus $\$ 1.12$ billion). Default on the part of a counter-party in a swap

\footnotetext{
${ }^{33}$ This section draws on Bodie and Merton (2002) and Merton (1990, 1999, 2002).
} 
contract results in the flow of payments being interrupted: the other party loses the diversification the swap provided, which can be rebooked with a different counter-party.

The potential exposure of foreign investors is probably less for the swap than for direct transactions in individual stocks. Not only because swaps only imply an exposure to flows of returns, rather than to the total value of the underlying asset. It is also more difficult to manipulate a broad market index than the price of a single stock. Even if settlement intervals for swaps are standardized at six months or one year, the calendar settlement dates will differ for each swap, depending upon the date of its initiation. Hence, with some swaps being settled every day, manipulators would have to keep the prices of shares permanently low to succeed.

Furthermore, with the settlement terms of swaps based on the per-period rate of return, an artificially low price (and low rate of return) for settlement this year will induce an artificially high rate of return for settlement next year. Thus, gains from manipulation in the first period are given back in the second, unless the price can be kept low over the entire life of the swap. Since typical swap contract maturities range from two to ten years (with semi-annual or annual settlements), this would be difficult to achieve.

The hypothetical equity swap just described enables pension funds to achieve broader international diversification. A different type of swap could enable them to hedge equity risk altogether. This would be particularly important for people in countries where there is no local entity, including the government, capable of issuing fixed-income securities that are free of all risk.

This second type of swap would call for the pension fund to swap the total return on its equity portfolio for a risk-free interest rate denominated in a "strong" currency or in units of constant purchasing power. This hypothetical swap would work the same way as the one in the previous example, except that the net cash flows produced by the swap would result in the pension fund receiving a risk-free rate of return. The counter-party must have a very good 
credit rating, or the swap must be guaranteed by a third party with a strong credit rating, or by a two-way mark-to-market collateral. As in the previous example, the pension fund would have to make payments to the swap counter-party only in years when its equity portfolio outperforms the risk-free rate.

Swaps are over-the counter (OTC) instruments, traded outside organized exchanges. Trading swaps implies no capital requirements although mark-to-market collateralizing of swaps is wide-spread; there are no specific rules governing conduct, including risk management, imposing centralized trading, defining clearing and settlement rules, and losssharing rules in case of defaults. OTC derivative markets lack a formal structure, have no physical central trading place, and no clearing or settlement system. There is also no central mechanism to limit individual or aggregate risk taking and risk management is completely decentralized.

Swaps, however, are very different from traditional negotiated bilateral contracts. The size of the OTC derivatives market (about $\$ 100$ trillion of notional contracts outstanding, see Table 9) has meant that these contracts have become standardized, in particular with regard to the legal aspects of the contract and the procedure for enforcing them: ISDA provides standardized courts- and market-tested contracts. This makes a swap contract very different in cost and timeliness of execution from a one-off bilateral contract.

The idea of using swaps to diversify risk has been around for a long time. What is different today, and allows swaps to be used in significant size and at low cost in practice, is the convenience of an existing legal infrastructure. 
Table 9

Outstanding OTC derivatives by underlying instrument

Notional amounts outstanding

(U.S. dollar billion)

$\underline{\text { June } 1998 \quad \text { June } 2001}$

$72,143 \quad 99,755$

Composition

(per cent)

$\begin{array}{lrr}\text { Interest rate contracts } & 66.7 & 76.1 \\ \text { Foreign exchange contracts } & 30.6 & 20.5 \\ \text { Equity-linked contracts } & 1.9 & 2.0 \\ \text { Credit linked } & 0.2 & 0.7\end{array}$

Source: B.I.S., Triennial central bank survey of foreign exchange and derivatives market activity in 2001. Basel, March 2002.

Large macroeconomic risks can accumulate in the balance sheet of the government. Swaps can be used by governments to stabilize tax revenue and avoid the sudden accumulation of debt. Consider again a country like Taiwan exposed to a specific industry such as electronics. The accumulation of foreign debt denominated in foreign currency often occurs in states of the world where $R_{W}{ }^{E}$ is low and tax revenue is correspondingly low. An instrument that allowed the government to reduce its exposure to a specific industry would stabilize tax revenue and reduce the sudden accumulation of foreign debt. As developed at length in Box 6.2, there are other examples of instruments besides swaps performing similar functions including structured notes and other collateralized instruments, which essentially allow a government to borrow against a future flow of income, e.g., the revenue from oil exports.

Box 6.3 Other derivatives used to diversify a country's risk

Emerging market borrowers have increasingly used innovative financial instruments to maintain access to international capital markets and attract capital flows, particularly at times when financial market turbulence reduces investors' appetite for emerging market debt. It is 
interesting to note (see Schinasi et al., 2000) that the issuance of this type of securities was particularly large following the South-East Asian and Russian crises and died out as markets conditions returned to normal. One example is structured notes, a fixed income security linked to a derivative-usually a swap, but also options, futures/forwards, or even credit-linked derivatives. Structures notes, as already mentioned, allow a borrower to hedge almost any risk: they could be designed to link the payment to capacity of the borrower. The very flexibility of this instrument is often the reason for its lack of liquidity in secondary markets. Being tailormade for a specific country it is not surprising that a structured note is not a very liquid instrument.

Collateralized bonds are not properly derivative instruments: they are really the securitization of future high-quality receivables, for instance oil revenue. In this sense they constitute senior debt, where the seniority is often guaranteed by incorporation of the issuing entity in a third country - as was the case with Pemex Finance, incorporated in the Cayman Islands, the entity used by the Mexican government to issue securitized notes. The entity is directly assigned the revenue from the receivables, which it uses to service the debt. As with the senior debt issued by some developing countries in the late nineteenth century, the problem with collateralized debt is that these instruments often earmark revenues, which constitute a major source of tax income. This automatically raises the cost of debt service on other forms of debt.

Consider, returning to the example used at the beginning of this section, a Taiwanese bank that lends to local electronics firms. Taiwan's comparative advantage lies in its firms' ability to produce world-class electronics at low cost; the bank's comparative advantage lies in its local knowledge, that is the ability to monitor the projects of local firms and their management. The domestic financial market, however, is too small to allow the bank to raise enough funds for its lending activities - the manifestation, at the individual bank level, of a macroeconomic phenomenon: the country needs portfolio capital investment to grow. 
By borrowing in the international capital market the bank exposes itself to an array of risks. Not only the traditional maturity mis-match, and possibly also a currency risk, but exposure to an industry sector, world electronics, over which it has limited, if any, control. What the bank monitors is the relative performance of domestic firms, but a slump in the world electronics market weakens the bank, quite independently of its ability in lending and monitoring. The bank would need an instrument that allows it to diversify credit risk, e.g. to swap default risk vis-à-vis its domestic borrowers for credit risk vis-à-vis a set of international borrowers. This is precisely what a credit derivative contract can produce.

A bank holding a concentrated loan portfolio has at least two ways to improve its riskreturn performance. First, it can actively manage the portfolio by trading loans: selling a loan, however, might negatively affect the bank's relationship with its customer when this discovers that his loan has been transferred to a different institution. Second it can use credit derivatives. A credit derivative allows the bank to swap credit risk vis-à-vis one borrower for credit risk vis-à-vis a different set of borrowers. The two transactions are typically disjoint. First the bank enters a default swap arrangement, essentially an insurance contract through which the bank buys, for a fee, insurance for the event of a default. Next the bank sells insurance to other banks buying exposure to the default risk of a different loan.

The transfer of credit risk can enhance the efficiency of credit markets by separating credit origination from credit-risk bearing. It can also help reduce the concentration of risk in banks' balance sheets: not only allowing banks to diversify their credit exposure across markets and sectors, as discussed above, but also by making it easier to shift such risks onto the balance sheets of non-bank institutions.

By there very nature, however, these derivatives spread credit risk to a broader set of market participants. This weakens the effectiveness of traditional credit-risk surveillance mechanisms - which are typically limited to banks — and increases the channels through which credit events can spread across institutions and markets. 
There is also a concern related to the effectiveness of these instruments at transferring default risk in the case of credit events. Sometimes it has been unclear whether the restructuring of a company would qualify as a "credit event" and thus trigger the insurance clause. ${ }^{34}$ Other cases were related to the purchase by banks of protection against the default of a client, triggered by his failure to make good on forward contracts for the delivery of a particular commodity - a form of credit default swap. The institutions selling such protection to the banks, often insurance companies, have argued that the banks never intended to take physical delivery of the commodity on the day the forward contract expired: the forward contract had been used by the bank simply to extend credit to its client — and the credit risk had been effectively transferred to the insurance companies: but this was not what the way the insurance companies interpreted the contract.

Table 10

\section{The Global credit derivatives market}

Net protection purchased by market participant (U.S. dollar bl.)

$\begin{array}{lr}\text { Banks } & 200 \\ \text { Corporations } & 80 \\ \text { Securities houses } & -10 \\ \text { Hedge funds } & -10 \\ \text { Insurance companies } & -300\end{array}$

Breakdown by instruments (per cent)

Credit default products $\quad 42 \%$ Total return swaps $\quad 11 \%$ Credit linked notes $\quad 12 \%$ Credit spread products $\quad 7 \%$ Baskets $8 \%$ Collateralized loan obligations $\quad 20 \%$

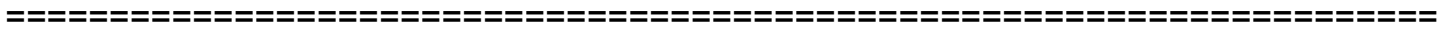
Source: IMF, Global Financial Stability Report, March 2002, p.37-38.

${ }^{34}$ On the legal enforceability of OTC derivative clauses see Schinasi at al. (2000) 


\section{Conclusions}

Discussions of the role of derivatives and their risks, as well as discussions of financial risks in general, often fail to distinguish between risks taken consciously and ones that are not. To understand the breeding conditions for financial crises the prime source of concern is not risk per se, but the unintended, or unanticipated accumulation of risks by individuals, institutions or governments including the concealing of risks from stakeholders and overseers of those entities.

This paper has analysed specific situations in which significant unanticipated and unintended financial risks can accumulate. We have focused, in particular, on the implicit guarantees that governments extend to banks and other financial institutions, and which may result in the accumulation, often unrecognized from the viewpoint of the government, of unanticipated risks in the balance sheet of the public sector.

Using the structural analogy between guarantees and options we have shown that a government's exposure to risk arising from a guarantee is non-linear. For instance, in the case of a government which guarantees the liabilities of the banking system, the additional liability transferred onto the government's balance sheet by a 10 percent shock to the capital of firms is larger the lower is that capital to start with. Recognizing this non-linearity in the transmission of risk exposures is essential to reduce the accumulation of unanticipated risks on the government's balance sheet.

Analyses of recent international financial crises recognize that the implicit guarantees governments extend to banks and corporations create the potential to greatly weaken their balance sheets. The attention, however, has mostly focused on the reasons why such guarantees exist, rather than on measurement of the exposures they create. This paper offers just such a framework for measuring the extent of a government's exposure to risk and how that exposure changes over time. 
We have discussed valuation of the assets of the banking system; drawing on the work of Gray (2001 and 2002) we have analysed the issues to be addressed in order to compute a country's value-at-risk; finally, we have used those insights to explain why the expected path of future fiscal variables (taxes and spending) should be adjusted whenever the value of the guarantees changes, such as, for instance, when the domestic economy weakens, or following an inflow of short-term capital.

Finally we have discussed ideas on how risk exposures can be controlled, hedged and transferred through the use of derivatives, swap contracts, and other contractual agreements. In emerging-market economies the domestic financial market typically allows limited diversification of risks. Internal diversification through industrial policy can be inefficient and costly to reverse. In such a situation, diversification through international capital mobility is the obvious alternative. However, the transfer across borders of the ownership of real and financial assets is only one way to achieve diversification, and it too can be costly to implement and even more costly to reverse. Often implementing these approaches to diversification conflicts with political objectives and constraints. Over-the-Counter (OTC) derivative contracts provide an appealing, non-invasive alternative way to transfer risk. Equity swaps, executed on a large scale, allow a country to diversify risk without shifting the ownership of assets or otherwise disturbing the domestic financial practices. 


\section{$\underline{\text { References }}$}

Blejer, Mario and Liliana Schumacher (2000), "Central Banks Use of Derivatives and Other Contingent Liabilities: Analytical Issues and Policy Implications”, Working Paper 00/66. Washington, IMF.

Bodie, Zvi, Akiko Mitsui and Peter Tufano (2002), "Corporate Pension Policy: Bethlehem Steel 2001. Harvard Business School, N-9-202-088.

Bodie, Zvi and Robert C. Merton (1993), "Deposit Insurance Reform: A Functional Approach", in Carnegie-Rochester Conference Series on Public Policy, A. Meltzer and C. Plosser (eds.), vol. 38, North Holland, pp. 1-34.

Bodie, Zvi and Robert C. Merton (2002), "International Pension Swaps", Journal of Pension Economics and Finance, vol.1 (January), pp. 77-83.

Borio, Claudio, Craig Firfine and Philip Lowe (2001), "Procyclicality of the Financial System and Financial Stability: Issues and Policy Options", mimeo, B.I.S.

Burnside, Craig, M. Eichenbaum and Sergio Rebelo (2002), "Government Guarantees and Self-fulfilling Speculative Attacks", mimeo, Northwestern University.

Caballero, Ricardo J. and A. Krishnamurthy (2000), "Dollarization of Liabilities: Underinsurance and Domestic Financial Underdevelopment”, NBER Working Paper No. 7792, July.

Caballero, Ricardo J. (2003), "The Future of the IMF", American Economic Review, Papers and Proceedings, May.

Caballero, Ricardo J. And S. Panageas (2003), "Hedging Sudden Stops and Precautionary Recessions: A Quantitative Approach", mimeo, MIT, January.

Calvo, Guillermo (2002), "Explaining Sudden Stops, Growth Collapses and BOP Crises", MundellFleming Lecture, IMF, November, forthcoming, IMF Staff Papers, 2003.

Cox, John C. and Stephen Ross (1976), "The Valuation of Options for Alternative Stochastic Processes," Journal of Financial Economics, 3 (January-March): pp. 145-66.

Credit Suisse (1997), CreditRisk+: A Credit Risk Management Framework. (Credit Suisse Financial Products.)

Crouhy, Michel, Dan Galai and Robert Mark (2001), Risk Management. New York: Mc Graw Hill.

Dornbusch, Rudiger (1998), "After Asia: New Directions for the International Financial System”, mimeo, MIT 
Dornbusch, Rudiger (2002), "A Primer on Emerging Market Crises", in S. Edwards and J. A. Frankel (eds.), Preventing Currency Crises in Emerging Markets. Chicago: The University of Chicago Press, pp. 743-754.

Feldstein, Martin (editor) (2003), Economic and Financial Crises in Emerging Market Economies. The University of Chicago Press.

Fischer, Stanley (2002), "Financial Crises and Reform of the International Financial System", NBER Working Paper No. 9297, October.

Garber, Peter (1999),"Derivatives in International Capital Flows" in Martin Feldstein (ed.) International Capital Flows. Chicago: Chicago University Press, pp. 386-407.

Gray, Dale F. (2001) “Macro Financial Risk Country Report: Thailand”, mimeo, MFRisk, Inc.

Gray, Dale F. (2002), “Macro Finance: The Bigger Picture”, Risk, June.

Gray, Dale F. Robert C. Merton and Zvi Bodie (2002), "A New Framework for Analyzing and Managing Macrofinancial Risk", Conference on Finance and the Macroeconomy, New York University, New York, October.

Hull, John C. (2000), Options, Futures and other Derivatives. New York, Prentice Hall, IV ${ }^{\text {th }}$ edition.

International Monetary Fund (2002), World Economic Outlook, April.

International Swaps and Derivatives Association (2002) "Enron: Corporate Failure, Market Success", available at www.fenews.com/fen26/enron1.html

Jeanne, Olivier and J. Zettelmeyer (2002), "'Original Sin', Balance Sheet Crises and the Role of International Lending", mimeo, IMF Research Department, November.

Kealhofer, Stephen (2003), "Quantifying Credit Risk I: Default Prediction”, Financial Analysts Journal, 59,1 (January/February)

Merton, Robert C. (1973), “The Theory of Rational Option Pricing”, Bell Journal of Economics and Management Science, 4 (Spring), pp. 141-83. (Chapter 8 in Continuous-Time Finance.)

Merton, Robert C. (1974), "On the Pricing of Corporate Debt: The Risk Structure of Interest Rates", Journal of Finance, (May), pp. 449-70. (Chapter 12 in Continuous-Time Finance.)

Merton, Robert C. (1977), "An Analytical Derivation of the Cost of Loan Guarantees and Deposit Insurance: An Application of Modern Option Pricing Theory", Journal of Banking and Finance, June. (Chapter 19 in Continuous-Time Finance.) 
Merton, Robert C. (1990), “The Financial System and Economic Performance”, Journal of Financial Services Research, 4 (December), pp. 263-300.

Merton, Robert C. (1992), Continuous-Time Finance. Revised Edition, Blackwell Publishers, Oxford.

Merton, Robert C. (1999), “Commentary: Finance Theory and the Shift to Integration”. Risk, July, p.50.

Merton, Robert C. (2002), "Future Possibilities in Finance Theory and Finance Practice", in Mathematical Finance: Bachelier Congress 2000, edited by H.Geman, D. Madan, S. Pliska and T. Vorst. Springer.

Merton, Robert C. and Zvi Bodie (1992), "On the Management of Financial Guarantees", Financial Management, Winter, pp. 87-109.

Merton, Robert K. (1936), "The Unanticipated Consequences of Purposive Social Action". American Sociological Review I, pp. 894-904.

Merton, Robert K. (1989), "Unanticipated Consequences and Kindred Sociological Ideas: a Personal Gloss", in Carlo Mongiardini and Simonetta Tabboni, eds., L'Opera di Robert K. Merton e la sociologia contemporanea. Genova: ECIG, 307-329.

Persaud, Avibash (2000), "Sending the Herd off the Cliff Edge: The Disturbing Interaction between Herding and Market-Sensitive Risk Management Practices". ERisk.

Reisen, Helmut (2001), "Will Basel II Contribute to Convergence in International Capital Flows?", mimeo, OECD Development Center.

Shinasi, Garry J, R. Sean Craig, Burkhard Dreed and Charles Kramer (2000), "Modern Banking and OTC derivatives markets", Occasional Paper \#203. Washington, IMF.

Tirole, Jean (2002) Financial Crises, Liquidity, and the International Monetary System. Princeton: Princeton University Press. 